\title{
ÉPOCA DE PLANTIO E ADUBAÇÃO DE Brachiaria brizantha cv. MARANDÚ E ESPAÇAMENTO DO MILHO COMO CULTURA ACOMPANHANTE, NA FORMAÇÃO DE PASTAGENS
}

\author{
JOÃo MENEzes de souza neto \\ Engenheiro Agrônomo
}

Orientador: Dr. JOSÉ VICENTE SILVEIRA PEDREIRA

Dissertação apresentada à Escola Superior de Agricultura "Luiz de Queiroz", da Universidade de São Paulo, para obtenção do titulo de Mestre em Agronomia. Área de Concentração: Ciência Animal e Pastagens

PIRACICABA

Estado de São Paulo - Brasil

Maio - 1993 
Dados Internacionais de Catalogação na Publicação (CIP)

DIVISÃO DE BIBLIOTECA E DOCUMENTAÇÃO - Campus "Luiz de Queiroz"/ USP

Souza Neto, João Menezes de

Época de plantio e adubação de Brm liurim hrizumlinc cv. marandú e espaçamento do milho como cultura acompanhante, na formação de pastagens / João Menezes de Souza Neto. - - Piracicaba, 1993.

$58 \mathrm{p}$

Dissertação (mestrado) - Escola Superior de Agricultura Luiz de Queiroz, 1993. Bibliografia.

1. Capim Marandú 2. Consorciação de cultura 3. Milho 4. Pastagem I. Titulo 


\section{ÉPOCA DE PLANTIO E ADUBAÇÃO DE 'Brachiaria brizantlia cv. MARANDÚ E ESPAÇAMENTO DO MILHO COMO CULTURA ACOMPANHANTE, NA FORMAÇÃO DE PASTAGENS}

\section{JOÃo MENEZES DE SOUZA NETO}

Aprovado em: 13.05.1993

\section{Comissão Julgadora:}

Dr. José Vicente Siveira Pedreira

IZ / SAA

Prof. Dr. Francisco Antonio Monteiro

ESALQ / USP

of. Dr. Antonio Luiz Fancelli

ESALQ / USP

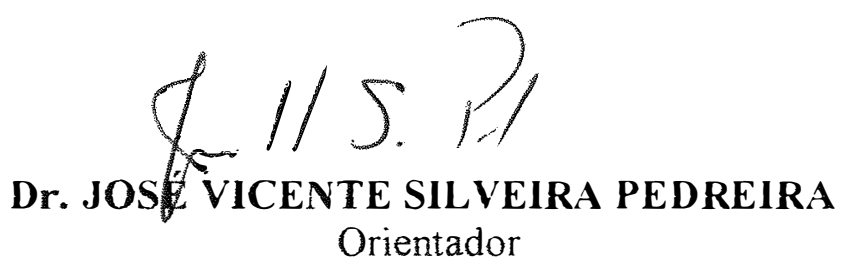


Aos meus pais, por terem me dado a vida e o máximo

de si pela minha educação e

Aos meus irmãos, pela união e o carinho

ofereço

Ao meu avò João, por ter me indicado o caminho correto a seguir

dedico 


\section{AGRADECIMENTOS}

São prestados os sinceros agradecimentos as seguintes pessoas e instituições:

- Dr. José Vicente Silveira Pedreira, pela amizade, apoio e orientação.

- Aos amigos Geovane Bonina Costa e Neivaldo Tunes Caceres pela amizade e colaboração.

- Aos professores do Departamento de Zootecnia pela orientação, ensinamentos e atenção.

- Ao Instituto de Zootecnia por ceder a área, pessoal de apoio e equipamentos.

- Ao Dr. Darci Beisman, pelo apoio e colaboração.

- Aos funcionários do Instituto de Zootecnia que colaboraram neste trabalho, em especial Domingos Alves e o amigo Diógenes Lopes.

- Aos pesquisadores do Instituto de Zootecnia pelo apoio e atenção dedicados a minha pessoa

- Ao Zootecnista Dr. Albino Luchiari Filho, Diretor do Instituto de Zootecnia de Nova Odessa, na época do experimento, pelas facilidades concedidas.

- Ao Eng. Agr. Dr. Francisco Antônio Monteiro, Diretor da Divisão de Nutrição Animal é Pastagens do Instituto de Zootecnia de Nova Odessa, na época do experimento, pelo apoio e orientações. 
- A Prof. Dra. Maria Cristina Nogueira e Prof. Dr. Irineu Humberto Packer pela atenção e orientação na análise estatística.

- Ao Ciagri pelo colaboração na analise estatística, em especial João Carlos Viana e Marcelo Alencar.

- As funcionárias da biblioteca da ESALQ - USP e em especial a Kátia Maria Pita de Andrade e Eliana Maria Garcia Sabino.

- Aos funcionários do Departamento de Zootecnia, em especial Sônia Ferreira e Américo Poleto.

- A CAPES pela bolsa de estudo concedida.

- A Associação Nacional de Difusão de Adubos e Corretivos (ANDA) pela ajuda financeira.

- A AGROCERES pela doação de sementes e ajuda financeira.

- A Minercal pela doação do calcário.

- A todos que direta ou indiretamente contribuiram para a realização deste trabalho. 


\section{SUMÁRIO}

Página

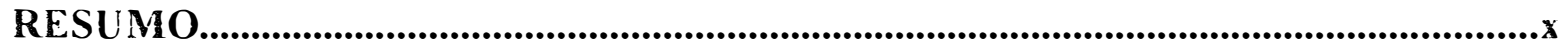

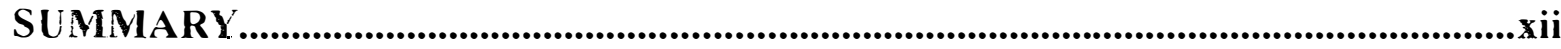

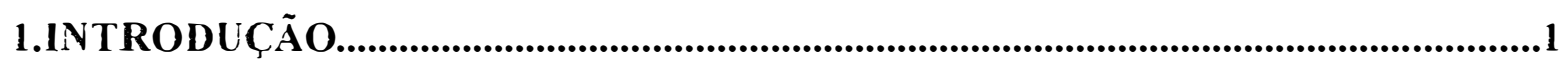

2. REVISÃO DE LITERATURA........................................................................4

2.1. A utilização de culturas acompanhantes na formação de pastagens ....................4

2.2. O milho como cultura acompanhante..........................................................8

2.3. O estabelecimento de pastagens e a utilização de Brachiaria brizantha..............11

2.4. Fatores que afetam a competição entre plantas ................................................... 14

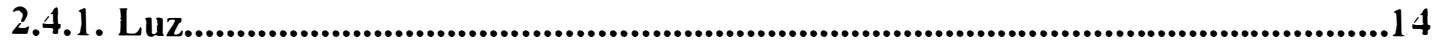

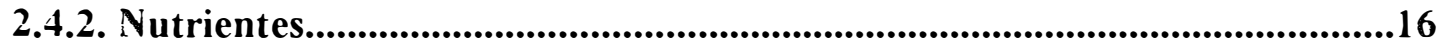

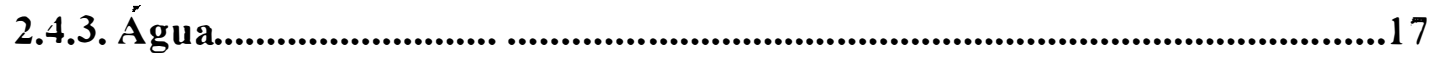

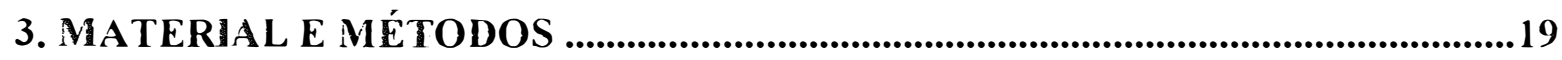

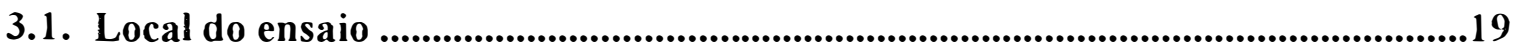

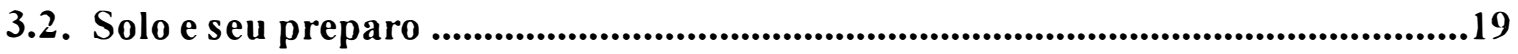

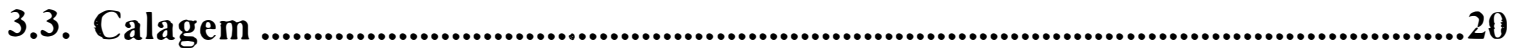

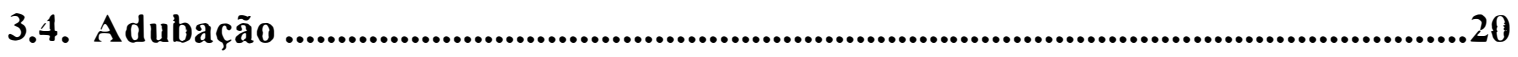

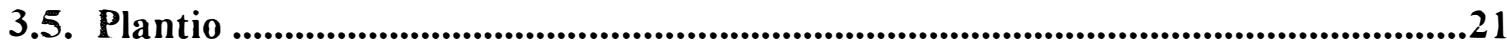

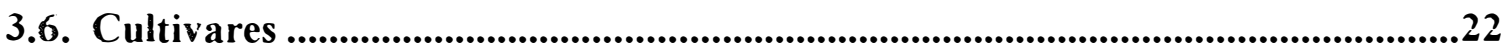




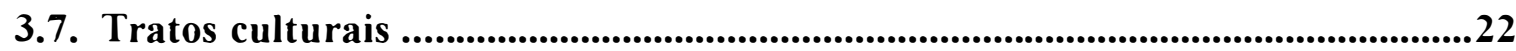

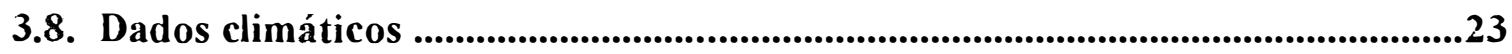

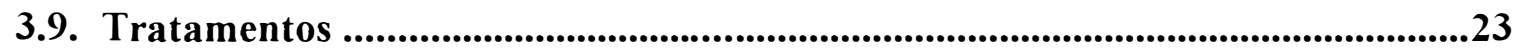

3.9.1 Espaçamento da cultura de milho.....................................................23

3.9.2 Época de semeadura da forrageira.................................................25

3.9.3 Adubação da forrageira........................................................................26

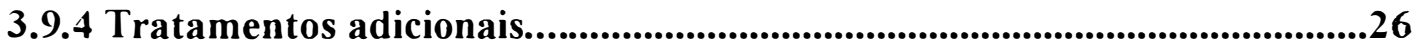

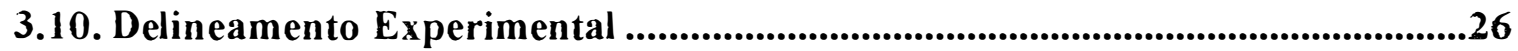

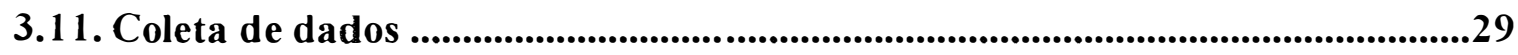

3.11.1. Coleta de dados do milho........................................................................29

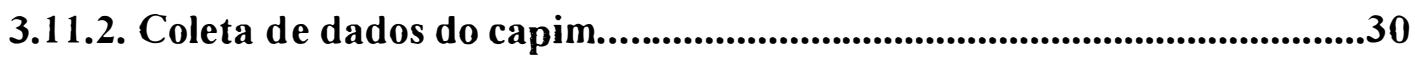

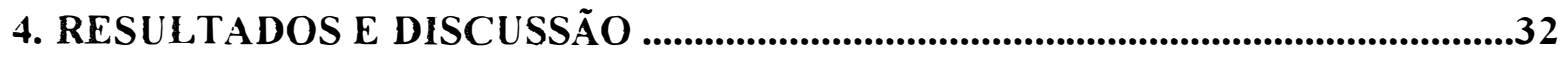

4.1. Efeitos dos tratamentos sobre a cultura do milho ...............................................32

4.1.1. População de plantas do milho nos diferentes tratamentos estudados...32

4.1.2. Efeitos dos tratamentos sobre a produção de matéria seca do milho.....33

4.1.3. Efeitos dos tratamentos sobre a produção de grãos de milho...................35

4.2. Efeito dos tratamentos sobre o capim ......................................................39

4.2.1. Efeitos dos tratamentos sobre a produção do capim..............................39

4.2.2. Efeitos dos tratamentos sobre a produção de matéria seca do capim....42

4.2.3. Efeitos dos tratamentos sobre a porcentagem de cobertura do solo pelo capim. 


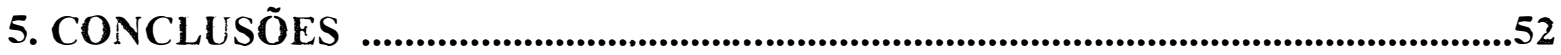

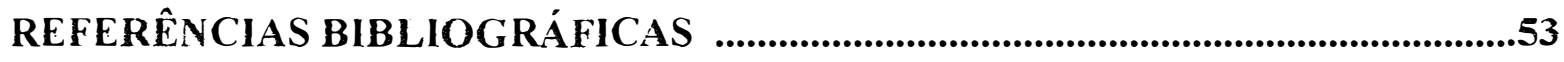




\section{FORMAÇÃO DE PASTAGENS DE Brachiaria brizantha cv. MARANDÚ COM MILHO COMO CULTURA ACOMPANHANTE}

Autor: JOÃO MENEZES DE SOUZA NETO

Orientador: DR. JOSÉ VICENTE SILVEIRA PEDREIRA

\section{RESUMO}

Conduziu-se um experimento a nivel de campo objetivando estudar, o estabelecimento de pastagens com milho como cultura acompanhante, a influencia da variação de épocas de semeadura e adubação do capim e do espaçamento do milho na produção de matéria seca e grãos do milho e número de plantas, produção e cobertura do solo com capim.

Foram testados dois espaçamentos do milho: A - linhas equidistantes $(1,25 \mathrm{~m}$ entre sulcos) e B - linhas modificadas (filas duplas com $0,50 \mathrm{~m}$ entre sulcos e $2,0 \mathrm{~m}$ entre 2 filas duplas). Dentro de cada espaçamento, estudou-se o efeito de quatro épocas de semeadura do capim, em relação à época de plantio do milho $(0 ; 21 ; 42$ e 63 dias após a implantação da cultura) e estudou-se o efeito da semeadıra do capim com e sem adubo.

O espaçamento modificado teve um efeito depressivo sobre a produção de grãos de milho porém favoreceu a produção de matéria seca e porcentagem de cobertura do solo com o capim aos 2 meses após a colheita do milho, enquanto que aos 7 meses observou-se o melhor efeito foi para o espaçamento de linhas equidistantes. 
As épocas de semeadura do capim utilizadas não influenciaram as variáveis estudadas para o milho, porém quando se semeou o capim mais tardiamente em relação ao plantio do milho, houve prejuizo para o capim.

A adubação do capim não apresentou efeito significativo, nas condições em que o experimento foi realizado. 


\title{
FORMATION OF PASTURES OF Brachiaria brizantha cv. MARANDÚ WITH CORN AS COMPANION CROP
}

\author{
Author: JOÃO MENEZES DE SOUZA NETO \\ Adviser: DR. JOSÉ VICENTE SILVEIRA PEDREIRA
}

\section{SUMMARY}

An experiment was carried out in at field conditions in order to study, on pasture stablishment with companion crop, the effects of several time of sowing and fertilization of the grass and the space of corn on the stand, dry matter and soil cover by the grass.

Two types of space of corn was devised: A - simple drills $(1,25 \mathrm{~m}$ between drills) and double drills (double drills with $0,50 \mathrm{~m}$ between drills and 2,0m between double drills). Within each space of corn, it was devised the effect of four times of grass sowing, in relation to the date of corn plantation $(0 ; 21 ; 42$ and 63 days after corn implantation) and the sowing was realized with or and without adubation.

The double unils of corn reduced its production of grain, but the dry matıcr and grass coverwas increased at two months after corn harvest. At 7 months after corn harvest, the best effect was observed for a simple drills. 
The times of sowing of grass didn't influence corn production but when the grass was sowed later in relation of corn planting; the grass was damaged.

The fertilization at the sowing of the grass didn't present significant effects on the conditions that the experiment was realized. 


\section{1 - INTRODUÇÃO}

As pastagens no Brasil são, em sua grande maioria, estabelecidas em solos de baixa fertilidade natural ou em solos degradados.

A utilização de práticas como adubação ou manejo adequado de pastagens não são comuns nos empreendimentos de pecuária de corte e leite ocorrentes no Brasil. Em decorrência deste fato, as pastagens tem baixa capacidade de suporte e se encontram em progressiva degradação. Conseqüentemente a formação ou reforma de pastagens se torna uma prática rotineira em propriedades com exploração pecuária.

O estabelecimento de forrageiras melhoradas ocorre em substituição as pastagens nativas, que normalmente suportam baixas lotações, na permutação de culturas que apresentam baixa rentabilidade, assim como a reforma de pastagens depauperadas pelo seu mau uso e manejo.

Devido a grandes investimentos necessários para a instalação de uma pastagem, tem-se tentado várias técnicas visando a diminuição dos custos desta prática. Entre essas técnicas pode-se citar a utilização de forrageiras menos exigentes em fertilidade do solo e de propagação por sementes, utilização de fontes de nutrientes mais baratas na adubação, como o fosfato de rocha, rotação com culturas anuais e uso de culturas acompanhantes.

A utilização de culturas acompanhantes, no estabelecimento de forrageiras, tem sido uma prática muito utilizada na formação e reforma de pastagens com o objetivo de atenuar as despesas relativas a correção e preparo do solo e o controle de plantas daninhas. 
Várias culturas tem sido utilizadas, tais como, milho, sorgo, arroz, mandioca e algodão, entre outras. $\mathrm{O}$ milho têm sido empregado em maior número de situações devido a sua tradição de cultivo nas propriedades agricolas, bem como sua boa adaptação quando plantado em consórcio. Esta cultura apresenta grande número de cultivares comerciais adaptados as diferentes regiões ecológicas. É um produto de fácil comercializaçào e normalmente a colheita paga os seus custos de produçào.

Os capins multiplicados por sementes e, ou, estolhos, podem ser estabelecidos com cultivo acompanhante. Entre as gramíneas mais utilizados pelos pecuaristas na década de oitenta está a Brachiaria brizantha c.v. Marandú. Este capim teve grande aceitaçào devido a sua boa produçào de matéria seca, palatabilidade e produçào de sementes, além de sua melhor tolerància ao frio, seca e ao ataque a cigarrinha-das-pastagens.

Esta gramínea possui agressividade e rápido estabelecimento, sendo muito competitiva com plantas invasoras, proporcionando maior cobertura da pastagem sobre o solo quando as condições de solo e clima lhe são favoráveis.

O estabelecimento de forrageiras com a utilizaçào de culturas acompanhantes ocorre sob condições de competição entre a cultura e a pastagem. Assim nem sempre se obtém sucesso devido ao efeito depressivo que uma espécie exerce sobre a outra.

O conhecimento da maneira como o capim e o cultivo acompanhante são afectados pela competição por água, luz e nutrientes, é de grande importància para o êxito na formaçào da pastagem e produçào satisfatória da cultura. 
A maneira como é implantada a cultura em consórcio com o capim, a disposição das plantas, época e forma de estabelecimento da forrageira e niveis de adubação, influem acentuadamente na competição entra as plantas.

Porém a carência de estudos nesta área leva o pecuarista a adotar práticas antigas já que não conta com outras alternativas de maior eficácia, tanto para se obter maior produção da cultura como o estabelecimento adequado da pastagem.

A realização de trabalhos que possam identificar e analisar os diferentes fatores que causam variações na produção e desempenho dos dois cultivos associados é uma atividade que se faz necessária. Como é elevado o número de agentes que interagem neste tipo de consórcio, fica trabalhoso a sua realização em condições de campo uma vez que é dificil controlar os diferentes elementos que interferem na competição entre as plantas.

O presente trabalho visa estudar práticas culturais de plantio de pastagens com culturas acompanhantes, de maneira a encontrar subsidios para sua utilização mais eficiente. Assim são estudados: efeitos de espaçamento no cultivo de milho, época de semeadura e adubação do capim sobre a produção do milho e o estabelecimento das pastagens 


\section{2 - REVISÃO DE LITERATURA}

\section{1 - A utilização de culturas acompanhantes na formação de pastagens}

No Brasil existem atualmente $171,4 * 106$ ha de pastagens sendo que $37,5 \%$ são pastagens cultivadas e $62,5 \%$ são pastagens nativas. Sendo que nos últimos 30 anos tem ocorrido um aumento considerável das primeiras (FIBGE, 1982 citado por ROCHA, 1986).

A expansão da área de pastagen s cultivadas através da introdução de novas forrageiras, aliado a um manejo mais adequado tem proporcionado um aumento da produtividade da pecuária bovina.

Os solos reservados para pastagens, na maioria das vezes, foram os de baixa fertilidade natural, portanto menos indicados para agricultura. Os solos de melhor fertilidade só eram utilizados com pastagens após a exploração inicial com culturas, e portanto já desgastados e empobrecidos pelo uso intensivo e extrativo (PEREIRA, 1986; LOBATO et al., 1986). As pastagens estabelecidas nessas condições tem um maior volume de produção no primeiro ano de estabelecımento, decaindo nos anos seguintes, com consequente redução na capacidade de suporte (PEREIRA, 1986).

Um dos maiores problemas no estabelecimento e manutenção de pastagens, em solos brasileiros, reside nos niveis extremamente baixos de fósforo disponivel e total. Estes solos ainda apresentam alta capacidade de adsorsão de fósforo, em con- 
sequência de sua acidez e de teores elevados de óxido de ferro e alunínio (LOBATO, 1986).

O uso quase sempre necessário da adubação onera os custos de implantação de pastagens. Frequentemente as pastagens não são estabelecidas de maneira adequada devido ao alto custo de formação, em torno atualmente de 16-21 OTNs/ha (AGROCERES, 1988), equivalentes a US\$ 114-152,00/ha (dezembro de 1988).

Uma das alternativas usualmente empregadas, pelo pecuarista, para redução desse custo de implantação é a utilização de culturas anuais acompanhantes. As vantagens proporcionadas são os efeitos residuais dos fertilizantes aplicados para o cultivo anual, a utilização de credito rural (CORSI,1984), a diminuição de infestação de plantas daninhas (PADILLA, 1986; WILLEY, 1979), a proteção contra erosão quando a pastagem tem estabelecimento lento (WILLEY,1979) e o aumento da produção de forragem em uma mesma estação de crescimento (WILLEY, 1979).

Na região de Umuarama no Paraná, de uma área total de 809.244 ha de pastagens ocorre uma reforma anual de 97.101 ha. A área reformada com culturas acompanhantes é de 77.680 ha, ou seja $80 \%$ do total reformado, sendo as principais culturas utilizadas: algodão $(53,62 \%)$, milho $(36,38 \%)$ e mandioca $(10 \%)$ (Emater PR *).

Esta prática apesar de or frequentemente utilizada e de interesse para o produtor, apresenta inconvenientes quanto a uniformidade e velocidade de estabelecimento da pastagem.

Outras desvantagens desses cultivos associados seriam a dificuldade de mecanização devido aos ciclos diferentes da pastagem e da cultura e os diferentes reque- 
rimentos em fertilizantes, controle de pragas, doenças e plantas daninhas (WILLEY, 1979).

Na prática, o plantio de uma forrageira junto com a cultura do arroz tem resultado problemático. Usando-se pouca sementes da forrageira, a pastagem demora a formar; com altas quantidades de sementes do capim, este compete com a cultura, reduzindo a produção da lavoura (ZIMMER, 1983).

A associação de duas culturas terá maior sucesso quando as mesmas apresentam ciclos de crescimento diferentes onde os períodos de maior demanda por recursos não coincidam (WILLEY, 1979).

Quando culturas associadas são semeadas em ruas separadas e não a lanço, há um favorecimento no manejo pois as culturas podem então ser cuidadas como culturas puras (WILLEY \& OSIRU, 1972)

VEIGA, 1984 testou a implantação de 3 capins: colonião (Panicum maximum), quicuio-da-amazonia (Brachiaria humidicola) e andropogon (Andropogon gayanus); em 3 sistemas de plantio intercalar ao milho e arroz: semeadura da cultura e do capim mais adubo no mesmo sulco espaçado de $1,0 \mathrm{~m}$; semeadura da cultura adubada em sulco espaçado de $1,0 \mathrm{~m}$ e o capim, sem adubo, em sulco intercalar a cultura e semeadura da cultura adubada em sulcos afastados de $2,0 \mathrm{~m}$ e, intercaladamente, semeadura d: sapim com adubação. O Autor encontrou melhores resultados com o milho como cultura acompanhante em relação ao arroz e em análise econômica considerou como melhores tratamentos para o estabelecimento da pastagem, a associação de colonião e andropogon com milho nos dois primeiros sistemas. 
DIAS FILHO, 1986 observou que o A. gayanus, semeado após plantio do milho nas entrelinhas, apresentou sérios problemas de estabelecimento, provavelmente causados pelo sombreamento.

ZIMMER et al., 1986 trabalhou com Calopogonium mucunoides associado as culturas de milho, sorgo e arroz, visando a produção de sementes da leguminosa, sendo esta semeada em duas épocas: na mesma época da semeadura da cultura e 4 semanas após a semeadura desta. Os resultados encontrados demonstraram que as culturas tiveram produções semelhantes nas 2 épocas de semeadura da leguminosa. Porém a produção do calopogònio foi superior quando este foi semeado na mesma época que as culturas, e nesta época não diferiu significativamente da sua produção quando em cultura exclusiva.

As culturas acompanhantes podem trazer beneficios a formação das pastagens devido a proteção que oferece face as intempéries. KELLY (1972) relata que o siratro teve uma maior população no segundo ano de estabelecimento quando este foi semeado intercalado a cultura do sorgo, em relação a cultura solteira. Este fato ocorreu devido a proteção maior ao frio quando esta leguminosa foi semeada com o cereal.

VEIGA \& SERRÃO (1990) afirmam que pastagens parcialmente abafadas por in soras arbóreas apresentam-se mais verdes no período seco devido as árvores diminuírem a evaporação, insolação e ventos. 


\section{2 - O milho como cultura acompanhante}

GERALDI(1983), trabalhando com o desenvolvimento de um modelo estatístico para avaliar consórcio de milho e feijão encontrou uma pequena queda $(11,3$ \%) na produção de milho em consórcio enquanto que a produção de feijão sofreu um redução de $62,7 \%$. Este fato seria devido ao milho ser uma espécie agressiva e de rápido crescimento sofrendo menor competição em consórcio. Os cultivares mais produtivos em mono cultivo foram os melhores em consórcio porém foram os que mais afetaram o feijão.

Quando se observam queda da produção do milho em consórcio, a diminuição do rendimento desta cultura deve-se, muitas vezes, a menor densidade utilizada (AIDAR \& VIEIRA, 1979).

SANTA-CECÍLIA (1978) testou 3 populações de milho; 20, 40 e 60.000 plantas/ha, consorciado com feijão, e semeado em 2 épocas: junto com a semeadura do milho e no inicio de seu secamento. Não se encontrou efeito da presença do feijão na produtividade do milho, sendo este afetado apenas por suas menores densidades. A cultura do feijão, quando semeada na mesma época que o milho, foi afetada pela presença deste principalmente quando se trabalhou com populações maiores. Quando semeado após o inicio do secamento do milho, o feijão não foi afetado pela população do milho. VEIGA (1982) afirma que no consórcio de milho e feijão, as populações de feijão normalmente utilizadas não concorrem com a cultura do milho e podem ser aumentadas quando se faz o consórcio no verão, época de maiores precipitações. SILVA \& VIEIRA (1981) e CORREIA et al. (1982) também obtiveram resultados semelhantes. 
A queda de produção de feijão em consórcio com o milho deve-se principalmente a uma menor produção de sementes por vagem. Este fato seria explicado pelo pequena competição do milho nos estágios iniciais de formação das vagens tornando-se mais acentuada, posteriormente quando as sementes da vagem estariam sendo formadas. Este fato é observado quando se semeia feijão de maturação precoce que se desenvolve antes do milho ter crescido o suficiente para ser efetivamente competitivo (WILLEY, 1979).

A semeadura da planta forrageira com cultivo acompanhante poderia ser feita na mesma época, desde que guardando-se a profundidade de semeadura ideal da forrageira de 2-4 cm (CNPGC, 1983), 0,6-1,2cm (CORSI, 1984).

A semeadura da forrageira associada, no inicio do estágio de desenvolvimento do milho, tem o objetivo de favorecer o estabelecimento da pastagem. Neste caso, a produtividade da cultura poderá ser prejudicada, dependendo da densidade de semeadura, da espécie forrageira e do espaçamento entre o milho e a planta forrageira (CORSI, 1984; MACEDO \& ZIMMER, 1990).

O estabelecimento da forrageira após 45 dias da implantação do milho não afeta a sua produtividade. BLANCO (1972) demonstrou que após esse prazo a ocorrência de plantas daninhas não afetou a cultura do milho.

O estabelecimento ma - tardio do capim torna a competição mais desfavorável a este, pois o sombreamento e a competição com o milho vão se tornando maiores. LOPEZ \& MAESTRI, 1973 demonstraram que o indice de área foliar do milho aumenta com seu desenvolvimento e é máximo ao redor de 92 dias após a emergência. 
ANDRADE et al., 1977 estudando taxa de assimilação de matéria seca e nutrientes durante o ciclo de produção do milho encontrou uma elevada extração de nutrientes e acúmulo de matéria seca a partir de 40 dias sendo o máximo de acumulação ocorre em torno de 100 a 106 dias de crescimento da cultura.

Uma maneira de atenuar a competição entre plantas é através da alteração do sistema de plantio, modificando o espaçamento utilizado. O Uso Eficiente da Terra (U.E.T.) aumentou de 45 a 55\% quando se modificou o espaçamento do milho e feijão em consórcio (FANCELLI *). Foi utilizada uma semeadura de 2 linhas de milho alternadas com 4 linhas de feijão, com o espaçamento constante de $0,5 \mathrm{~m}$ entre linhas tanto para o milho como para o feijão.

Este tipo de plantio em faixa tende a favorecer a cultura dominada na consorciação. Quando se testou 2 sistemas de plantio em faixa de milho e feijão: com 4 linhas de milho e 4 linhas de feijão e com 3 linhas de milho e 6 de feijão comparados com suas culturas solteiras em várias regiões do Paraná (IAPAR, 1980), conseguiuse uma maior produção do feijão no segundo sistema de plantio.

WILLEY \& OSIRU, 1972 testando 2 combinações de milho e feijão semeados em faixas e comparando-as com suas culturas exclusivas, e encontrou uma menor produção por planta do milho quando este foi semeado em cultura exclusiva. $\mathrm{O}$ milho sofre mais a ompetição quando em cultura exclusiva que quando em mistura com o feijão.

A utilização de culturas acompanhantes na formação de pastagens aumenta a competição por água, luz e nutrientes. VIEGAS(1978) recomenda em cultivos tardios de milho, em situações de media disponibilidade de água, uma população de 3040.000 plantas/ha. 


\section{3 - O estabelecimento de pastagens e a utilização Brachiaria brizantha.}

A pecuária tem sido uma atividade pouco competitiva quando comparada com a agricultura, devido aos lentos e baixos retornos que oferece ao produtor. A formação de pastagens é um processo dispendioso, exigindo em geral, o uso de insumos, principalmente fosfatos. Vários aspectos devem ser analisados na formação de pastagens, tais como: espécie ou mistura a ser semeada, condições de solo, exigência das plantas, fertilizantes necessários, quantidade e forma de aplicação mais adequada, frequência de adubações e produtividade esperada (LOBATO, 1986).

A correção das deficièncias minerais e de acidez do solo são fundamentais para um bom estabelecimento e formação de pastagens. A aplicação a lanço de adubos de alta higroscopicidade normalmente não causam problemas a emergência e ao estabelecimento de forrageiras. Por outro lado, a aplicação desses adubos em sulcos, especialmente se ficarem muito próximo das sementes, como em misturas de sementes e adubos, poderá resultar em reduções da germinação, devido a alta higroscopicidade desses adubos que absorvem a água em torno da semente, e podendo provocar danos no tecido das mesmas. Isto se acentua mais se houver pouca umidade no solo (ZIMMER et al., 1983).

A deficiência ou o excesso de algum elemento no solo dificilmente impede a germinação, mas pode provocar a morte ou afetar o crescimento de plantas novas, o que dificulta o estabelecimento da pastagem.

A época de plantio tradicionalmente utilizada para pastagens é bastante ampla, e vai desde as primeiras chuvas, no inicio de setembro até março. Os plantios 
efetuados fora das épocas mais favoráveis acabam formando o pasto no $2^{\circ}$ ano mas deve-se atentar para o fato de que o plantio feito na época correta, se obtém um maior número de plantas com mesma quantia de semente, o que resulta numa maior capacidade de competição com plantas invasoras, maior rapidez na formação da pastagem, menor erosão do solo e, o que é mais importante, a pastagem poderá ser usada mais rapidamente, resultando em um retorno mais rápido do investimento feito na pastagem. Uma pastagem bem formada, de gramíneas tropicais, possui uma população de 10 a 20 plantas/m² (ZIMMER, 1983; DIAS FILHO, 1986).

A produtividade de uma espécie mais producente e agressiva pode ser afetada por outras plantas menos competitivas como é o caso de estabelecimento de forrageiras, mais eficientes, concorrendo com plantas invasoras (VIEIRA, 1974).

Em trabalho realizado por VIEIRA, 1974; a maior frequência de ocorrência de B. decumbens ocorreu quando além da realização de capinas utiliza-se espaçamento que desfavoreceramm a presença de invasoras. Espaçamentos menores, 0,40 e $0,80 \mathrm{~m}$, proporcionaram uma menor competição com invasoras em relação a espaçamentos maiores, 1,20 e $1,40 \mathrm{~m}$. Com espaçamentos de $0,40 \mathrm{~m}$ houve um aumento no número de perfilhos, na produção de matéria seca e maior cobertura do solo pelo capim.

As quantias de sementes recomend tas variam de acordo com a forrageira utilizada. Para B. brizantha, NUNES et al. (1985) recomenda a utilização de 1,6 a $2,0 \mathrm{~kg} / \mathrm{ha}$ de sementes puras viáveis.

GHISI \& PEDREIRA (1986) citam a B. brizantha cv. Marandú como sendo umas das gramíneas mais propagadas no Brasil. Esta gramínea possui boa produção de matéria seca e sementes, maior tolerância a cigarrinha-das-pastagens e a 
condições de baixas temperaturas e seca. A B. brizantha e a B. ruziziensis devem ter espaçamento de semeadura mais estreitos que a B. decumbens.

A B. brizantha cv. Marandú tem mostrado resistência a cigarrinha-daspastagens, bom valor nutritivo e alta produção de massa verde. Também produz grande quantidade de sementes viáveis e ainda não se tem verificado fotossensibilização hepatogênica em bezerros, apresentando grandes perspectivas de utilização nas fases de desmama e engorda de bovinos (NUNES et al., 1984).

GREGOLIN (1986) afirma que atualmente mais de 90\% dos criadores interessados na formação e reforma de pastagens tem optado por essa gramínea.

Há uma predominância das braquiárias nos solos de pastagens de São Paulo, $54,23 \%$ do total, tendo em vista sua adaptação a solos de baixa fertilidade e fácil disseminação. As espécies mais difundidas são a Brachiaria decumbens (30,74\% da área total) e Brachiaria brizantha (13,13\% da área total), sendo que esta última foi a mais difundida entre os anos de 1984 e 1989, onde sua área aumentou de 2,50\% do total do estado para 13,13\% (FERREIRA et al., 1990).

PEREIRA (1986) afirma que a deficiência mais acentuada e generalizada em solos do Brasil é a de fósforo. A resposta a aplicação de nutrientes é tanto mais acentuadas quanto maior for a exigência das gramíneas e a presença ou não de legumino: 3. As branquiárias são consideradas plantas capazes de ve $e_{\imath} \cdot$ tar em solos com baixos teores de fósforo disponivel, isto é, são mais eficientes na sua utilização e não requerendo mais que $45 \mathrm{~kg}$ de $\mathrm{P}_{2} \mathrm{O}_{5} /$ ha, sendo que para a $\mathbf{B}$. humidicula foi determinado um nível crítico externo de $10 \mathrm{~kg}$ de $\mathrm{P}_{2} \mathrm{O}_{5} / \mathrm{ha}$, e para A. gayanus, B. decumbens e B. brizantha, o nivel crítico chega a $20 \mathrm{~kg}$ de $\mathrm{P}_{2} \mathrm{O}_{5} /$ ha. FERNANDES et al., 1990 trabalhando em solo de cerrado conseguiu, com a adição de calcário, gesso e 
adubação com nitrogênio, fósforo e potássio, um aumento em $85 \%$ da produção de matéria seca de B. brizantha em relação ao tratamento testemunha não adubado.

GUSS et al., 1990 estudou várias dosagens de adubação fosfatada no estabelecimento de B. brizantha. Foram testados 6 niveis de adubação com fosfato natural de Araxá associados ou não a $20 \mathrm{~kg}$ de $\mathrm{P}_{2} \mathrm{O}_{5} /$ ha de fósforo solúvel na forma de superfosfato simples. A forrageira foi cortada, aos 90 e 150 dias, para medir a produção de matéria seca. As doses ótimas, 579 e $593 \mathrm{~kg}$ de $\mathrm{P}_{2} \mathrm{O}_{5} / \mathrm{ha}$, respectivamente para primeiro e segundo corte, corresponderam ao aumento de produção de $39 \%$ e $30 \%$ no primeiro e segundo corte, respectivamente. Quando se usou fósforo solúvel associado ao fosfato de Araxá não se observou efeito significativo do fosfato natural.

\section{4 - Fatores que afetam a competição entre plantas}

\subsection{1 - Luz}

AGBOOLA \& FAYEMI,1971 estudaram leguminosas intercaladas ao milho onde o cereal não foi seriamente afetado pelas leguminosas mas estas foram afetadas pelo milho, principalmente devido ao sombreamento

SANTA-CECÍLIA (1978) afirmou que a produtividade de feijão em consórcio é baixa devido ao sombreamento deste pela cultura do milho.

VEIGA (1982) concorda com este Autor e sugere que o sombreamento sobre a leguminosa poderia ser diminuído aumentando-se o espaçamento entre as linhas de milho. Este fato não foi comprovado nos trabalhos estudados pelo mesmo Autor onde o milho teve sua produtividade diminuida sem melhora na produção do feijão. 
AIDAR et al., 1979 testando várias populações milho e feijão em consórcio obtiveram menor produção da leguminosa, a medida que se aumentava a população de plantas do milho. Os Autores consideraram que a principal causa da queda de produtividade dos feijoeiros foi o sombreamento quando era aumentado o número de plantas do milho. Essa possibilidade foi confirmada pelas precipitações pluviais que foram favoráveis ao feijão, e pelas condições aparentemente não limitantes de fertilidade do solo, nas condições em que o trabalho foi realizado.

O milho tem grande poder de competição, e este aumenta com o aumento de sua população de plantas na área. Provavelmente devido ao efeito de sombreamento, o milho deprime a produção do feijão (WILLEY \& OSIRU, 1972). Em consorciação, o milho é uma espécie das mais competitivas . Este fato poderia ser explicado, por este ter alto potencial de produção e do ponto de vista da interceptação da luz ocupar uma posição mais favorável no campo devido a seu maior porte.

Quando as plantas consorciadas apresentam diferentes coberturas ou estrutura de crescimento, ocorre um melhor aproveitamento da luz. Outra maneira de se aumentar a eficiência seria utilizar plantas de diferentes exigências por luz (WILLEY, 1979).

As plantas forrageiras tropicais são muito sensiveis ao sombreamento (LUDLOW, 1978 ) e a medid que a intensidade de sombreamento aumenta, a planta forrageira é a mais prejudicada pela competição por água, luz e nutrientes.

REYNOLDS, 1978 em experimento onde se testou a produção de matéria seca de diferentes gramineas desenvolvendo em associação com plantação de cocos, classificou as gramineas em 4 categorias de produção de matéria seca, em condições onde ocorria $50 \%$ de sombreamento: baixa produção $(<7.500 \mathrm{~kg} / \mathrm{ha})$, média produ- 
ção $(7,5-10.000 \mathrm{~kg} / \mathrm{ha})$, alta produção $(10-14.000 \mathrm{~kg} / \mathrm{ha})$ e de muito alta produção (14-16.000kg/ha). A Brachiaria brizantha foi classificada como de media produção, com $8.871 \mathrm{~kg} / \mathrm{ha}$.

\subsection{2 - Nutrientes}

Experimentos com pastagens, tanto de gramíneas como leguminosas, tèm mostrado resposta a adubação fosfatada, em especial na fase de estabelecimento Normalmente as maiores respostas a adubação fosfatada se observam com aplicações de 50 a $100 \mathrm{~kg}$ de $\mathrm{P}_{2} \mathrm{O}_{5}$ (solúvel em água)/ha. Os efeitos residuais podem ser bastante prolongados, sendo uma função, entre outros fatores, da quantidade de fósforo aplicada (LOBATO, 1986).

Quando doses mais elevadas são aplicadas em solos pobres ou que nunca receberam adubação fosfatada, este nutriente pode apresentar efeito residual prolongado no solo. Em áreas em que a agricultura precedeu a pastagem e o solo foi convenientemente adubado, as respostas a aplicação ou são pequenas ou não existem. Há evidèncias de que as espécies forrageiras diferem entre si no seu requerimento nutricional em relação ao fósforo e na sua eficiência de absorção e utilização deste nutriente (LOBATO, 1986).

GLORIA, 1986 afirma que, em geral, a grande maioria dos solos dc Brasil se caracteriza por serem solos altamente intemperizados e com baixa reserva de minerais (feldspatos e micas), passiveis através da intemperização, de fornecer quantidades apreciáveis de potássio às gramíneas forrageiras que em geral são exigentes em potássio. As necessidades de potássio só será sentida em pastagens somente após alguns anos de exploração da área, mas se evidenciará mais rapidamente nos solos 
mais arenosos, naqueles mais sujeitos a erosão e sob condições de precipitação pluvial mais intensa.

GLORIA, 1986 indica que o aproveitamento, de adubações de nitrogênio e fósforo, não é satisfatório quando os teores de potássio estiverem inferiores a 40ppm, e a produção deverá ser limitada devido ao suprimento de potássio. É provável que, estando os teores de nitrogênio e fósforo satisfatórios, o teor de potássio para obtenção de produções máximas deve ser superior a 60ppm.

Quando se tem consorciação de plantas que possuem período de crescimento sinilar mas que podem ter pico de demanda de nutrientes em diferentes estágios de crescimento, este fato permitiria que a demanda não excedesse a taxa pela qual os nutrientes podem ser supridos pelo solo, atendendo as exigências das plantas (WILLEY, 1979)

Assim como a época de semeadura, a adubação pode influenciar o estabelecimento de pastagens associadas a culturas anuais, diminuindo a competição por nutrientes. Em experimento realizado por PADILLA et al. (1986) onde se usou 3 doses de adubo ( $00 ; 0,5 ; 1,0$ t/ha) da fórmula 06-3,2-16 no estabelecimento do capim estrela (Cynodon nlenfluensis) encontrou-se uma melhora de até 160\% na produção de matéria seca em relação a área não adubada.

\subsection{3 - Água}

AGBOOLA \& FAYEMI, 1971 estudou entre leguminosas intercaladas ao milho, em várias estações de crescimento do milho e sugere que as leguminosas podem competir com o cereal por água e nitrogênio durante a estação seca e por nitro- 
gênio na estação chuvosa. O Autor recomenda o plantio de milho e leguminosas intercalares na estação chuvosa onde há umidade suficiente para ambas as culturas.

MACEDO \& ZIMMER, 1990 realizaram trabalho de implantação de pastagens de B. brizantha cv. Marandú em plantio simultâneo ao milho em solo de areia quartzoza (teor de areia $>70 \%$ ) em Bandeirantes - MS. Foram testados 5 densidades de sementes puras viáveis (SPV) na semeadura do capim: $0 ; 0,75 ; 1,5 ; 3,0$ e 6,0 kg de SPV/ha) em 2 épocas, janeiro e outubro de 1988. Os resultados encontrados demonstraram um efeito significativo $(\mathrm{P}<0,05)$ depressivo do capim na produção de grãos de milho quando utilizadas taxas de semeadura superiores a 1,5 kg de SPV/ha. As produções de milho caíram de 2.097 para $1.362 \mathrm{~kg} / \mathrm{ha}\left(1^{\circ}\right.$ ano) e, de 3.754 para $2.992 \mathrm{~kg} / \mathrm{ha}\left(2^{\circ} \mathrm{ano}\right)$ nas parcelas com $1,5 \mathrm{~kg}$ de SPV/ha, enquanto que as produções de matéria seca da B. brizantha foram em média, de 6.348 e $3.951 \mathrm{~kg} / \mathrm{ha}$ para o $1^{\circ} \mathrm{e}$ $2^{\circ}$ ano respectivamente.

A produção do capim foi maior no $1^{\circ}$ ano quando a época de plantio foi mais desfavorável ao milho e este teve menor desenvolvimento e produção, sendo esta mais afetada pela presença do capim. A produção do cereal foi maior e menos afetada pela presença do capim, em densidades de semeadura maiores que $1,5 \mathrm{~kg}$ de SPV/ha, no plantio em outubro, quando as condições de precipitação e temperatura eram mais favoráveis. 


\section{3 - MATERIAL E MÉTODOS}

\section{1 - Local do ensaio}

O experimento foi instalado no Municipio de Nova Odessa, Sào Paulo, em área pertencente a Estação Experimental da Divisão de Nutrição Animal e Pastagens do Instituto de Zootecnia da Secretaria da Agricultura do Estado de Sào Paulo. A área total do local onde foi instalado o experimento era de 1,2 ha e a área útil do experimento de 0,2 ha.

\section{2 - Solo e seu preparo}

A área utilizada era parte de uma gleba de meia encosta, de inclinação suave e uniforme. O solo tinha sido cultivado anteriormente durante 2 anos com soja (Glicine max,) e se encontrava infestada de invasoras, principalmente, carrapicho (Cenchrus echinatus Linn.), picão (Bidens pilosa L.), capim colchão (Digitaria horizontalis Willd) e em menor proporção Brachiaria humidicola.

A composição química média do solo foi determinada em análise realizada, a partir de uma amostra composta da área total do local do experimento, pelo Laboratório de Análise de Solos da Nutrição Mineral de Plantas do Departamento de Quimica da Escola Superior de Agricultura "Luiz de Queiroz". Os resultados estão no Quadro I. 
QUADRO I - Resultado de análise química do solo da área do ensaio.

\begin{tabular}{lcccccccc}
\hline & $(\%)$ & $(\mathrm{ppm})$ & & $(\mathrm{meq} / 100$ & $\mathrm{cm}^{3}$ de solo $)$ & & $(\%)$ \\
\hline 4,30 & 3,20 & 15,50 & 0,24 & 2,11 & 1,05 & 3,61 & 7,00 & 48,5 \\
\hline
\end{tabular}

O preparo de solo foi realizado na área total do ensaio e consistiu de uma aração e uma gradagem realizadas no mês de outubro e outra gradagem no final de novembro de 1988 , próximo a realização do semeadura. O preparo foi realizado tardiamente em relação a época normal de preparo de culturas anuais devido ao atraso de chuvas no periodo.

O solo estava a época da semeadura livre de plantas daninhas e em condições adequadas para receber a semeadura.

\section{3 - Calagem}

A calagem foi realizada em outubro com calcário de PRNT $=105 \%$ em 2 aplicações, $50 \%$ da quantia antes da aração e $50 \%$ antes da primeira gradagem. A quantia utilizada foi o equivalente a $1,67 \mathrm{t} / \mathrm{ha}$.

\section{4 - Adubação}

A adubação do milho foi realizada com semeadora e adubadora mecanizada na época da semeadura da cultura. A quantia de adubo usada na semeadura foi 55 gramas de 05-15-10 por metro linear da cultura equivalentes a $22 \mathrm{~kg} / \mathrm{ha}$ de $\mathrm{N}, 66$ $\mathrm{kg} / \mathrm{ha}$ de $\mathrm{P}_{2} \mathrm{O}_{5}$ e $44 \mathrm{~kg} / \mathrm{ha}$ de $\mathrm{K}_{2} \mathrm{O}$. 
A cobertura do milho foi feito no dia 10 de janeiro de 1989, 38 dias após a semeadura do milho, manualmente. O adubo utilizado foi o sulfato de amônio na quantia de 19,5 g por metro linear da cultura equivalentes a $31,2 \mathrm{~kg} / \mathrm{ha}$ de $\mathrm{N}$.

A adubação da forrageira nas parcelas dos tratamentos com gramínea adubada foi realizado manualmente no sulco de semeadura evitando - se o contato do adubo com as sementes. A quantia de adubo utilizada foi 20 gramas de 05-15-10 por metro linear da gramínea equivalentes a $16 \mathrm{~kg} / \mathrm{ha}$ de $\mathrm{N}, 48 \mathrm{~kg} / \mathrm{ha}$ de $\mathrm{P}_{2} \mathrm{O}_{5}$ e $32 \mathrm{~kg} / \mathrm{ha}$ de $\mathrm{K}_{2} \mathrm{O}$.

\section{5-Plantio}

O semeadura do milho foi realizado com semeadora mecanizada no dia 02 de dezembro de 1988. O semeadura foi realizado tardiamente em relação ao semeadura normal da cultura de milho para a região, outubro, devido ao atraso das chuvas no ano de implantação do ensaio.

A semeadura do milho em um espaçamento era feito ao longo de todo o comprimento do bloco para se evitar manobras e mudanças no espaçamento entre as semeaduras da máquina.

A semeadora foi regulada para colocar no solo 8 sementes de milho por metro linear para se conseguir um stand final de 5 plantas por metro linear ou 40.000 plantas/ha. Após 19 dias da semeadura do milho foi feito um replantio manual nas parcelas que apresentaram falhas.

A forrageira foi plantada manualmente a profundidade de 0,5 a $2,0 \mathrm{~cm}$ colocando - se aproximadamente 0,9 gramas de sementes por metro linear equivalentes 
a $15,0 \mathrm{~kg} /$ ha de sementes com $35 \%$ de valor cultural ou $5,25 \mathrm{~kg} / \mathrm{ha}$ de sementes puras viáveis.

O espaçamento da forrageira utilizado foi de 0,40 metros entre as linhas da forrageira e a 0,40 metros da linha de milho.

\section{6 - Cultivares}

A variedade de milho utilizada foi a AG-106. As suas principais características deste híbrido duplo de ciclo normal são : alta prolificidade em lavouras de 40.000 plantas/ha, excelente resposta a adubaçào, boa produçào de silagem e boa adaptaçào aos semeaduras normais e tardias.

A forrageira utilizada foi a Brachiaria brizantha cv. Marandú. Este foi o capim mais plantado no Brasil na década de 80 devido as suas características como resistência a cigarrinha-das-pastagens, bom valor nutritivo, alta produçào de massa verde e grande produçào de sementes viáveis.

\section{7 - Tratos culturais}

Após o semeadura do milho, os tratos culturais realizados foram apenas adubaçào de cobertura aos 38 dias do implantada a cultura e capinas manuais de maneira que a lavoura ficou livre de plantas daninhas ate 63 dias após sua instalaçào. A incidència de pragas e doenças foi bastante baixa, nào sendo necessário nenhum controle. 


\section{8 - Dados climatológicos}

Durante a realização do experimento as precipitações e temperaturas médias observadas pela Estação Experimental de Nova Odessa foram as relacionadas na tabela 1 .

TABELA 1 - Dados climatológicos ocorridos no local do experimento, durante o periodo experimental (agosto/88-novembro/89).

\begin{tabular}{|c|c|c|}
\hline Mês & Temperatura $\left({ }^{\circ} \mathrm{C}\right)$ & Precipitações $(\mathrm{mm})$ \\
\hline Agosto & 21,4 & 0,2 \\
Setembro & 22,2 & 2,0 \\
Outubro & 21,9 & 146 \\
Novembro & 22,3 & 79,4 \\
Dezembro & 24,1 & 108,5 \\
Janeiro & 23,5 & 209,5 \\
Fevereiro & 24,1 & 209,0 \\
Março & 24,0 & 57,5 \\
Abril & 22,5 & 44,1 \\
Maio & 18,5 & 19,8 \\
Junho & 17,0 & 51,8 \\
Julho & 17,7 & 92,5 \\
Agosto & 18,3 & 18,4 \\
Setembro & 19,6 & 44,8 \\
Outubro & 20,8 & 116,0 \\
Novembro & 23,9 & 177,0 \\
\hline
\end{tabular}

\section{9 - Tratamentos}

\subsection{1 - Espaçamento da cultura de milho}

O espaçamento da cultura é um fàtor determinante na competição que ocorre entre a forrageira e o milho, sendo interessante se conseguir um arranjo que diminua a competição entre as espécies. 
O primeiro espaçamento utilizado neste trabalho, denominado como linhas equidistantes foi o com linhas de semeadura equidistantes e espaçadas de 1,25 metros entre si, conforme Fig. 1. Este espaçamento com 5 plantas por metro linear perfaz um stand de 40.000 plantas/ha . Este nível populacional é considerado como ideal para situação de déficit hídrico (VIEGAS, 1978) onde se tem uma maior competição entre plantas por água e nutrientes que é o caso do experimento em questão.

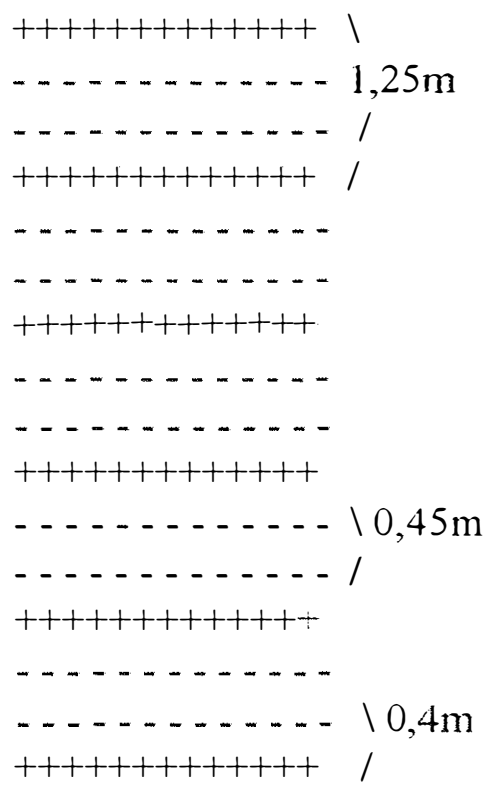

1 - Espaçamento de linhas equidistantes 2 - Espaçamento modificado Forrageira

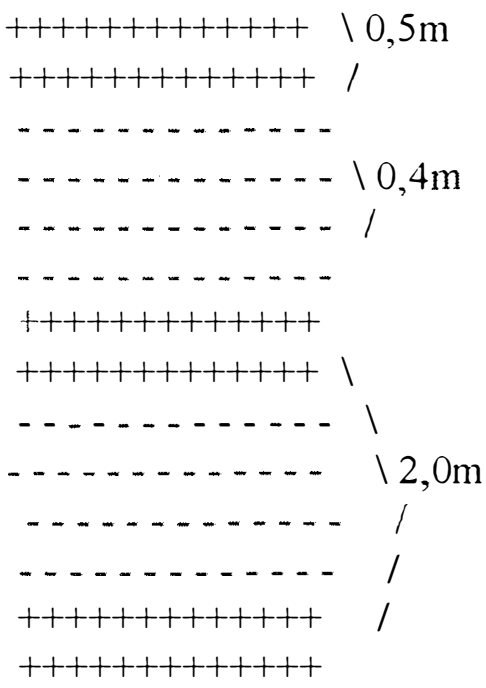
++++++++ Milho

FIG. 1 - Espaçamentos utilizados no experimento.

O segundo espaçamento utilizado denominado neste trabalho como modificado é uma tentativa de se conseguir uma melhor distribuição espacial das plantas, de maneira a diminuir a competição entre a forrageira e a cultura acompanhante. Nesta situação temos um conjunto de 2 linhas de milho em fila dupla espaçadas entre si de 
0,50 metro com 2,00 metros de distância de outro conjunto de duas linhas e assim por diante, conforme esquema das parcelas na Fig. I. Também neste caso com 5 plantas por metro linear perfazemos um stand de 40.000 plantas/ha.

Foi feito avaliação e análise da população de plantas de milho e esta não diferiu estatisticamente entre os tratamentos, porém a população de plantas de milho obtida, 50.333,32 plantas/ha, foi superior a planejada no início do experimento, de 40.000 plantas/ha. Este fato se deveu às condições climáticas ocorridas na sua implantação onde a ocorrência de um "veranico" que prejudicou a germinação cultura. Foi feito uma replantio para corrigir falhas na população de plantas de milho e após esta, não foi feito raleação pois seria realizada tardiamente prejudicando o sistema radicular do milho.

Em consorciação de milho e feijão, este tipo de espaçamento aumentou em 45 a $55 \%$ o Uso Eficiente da Terra (U.E.T.) (FANCELLI, comunicação pessoal).

\subsection{2 - Época de semeadura da forrageira}

A época de semeadura da forrageira na entrelinha da cultura acompanhante é determinante na competição por água, nutrientes e principalmente luz pois as gramineas tropicais são pouco tolerantes ao sombreamento (LUDLOW, 1978).

As épocas testadas no presente ensaio foram:

Época 1: Plantio da forrageira na mesma época que a semeadura do milho.

Época 2: Plantio da forrageira 21 dias após a semeadura do milho.

Época 3: Plantio da forrageira 42 dias após a semeadura do milho

Época 4: Plantio da forrageira 63 dias após a semeadura do milho. 


\subsection{3 - Adubação da forrageira}

A utilização de adubação visa favorecer o estabelecimento da forrageira pois diminui a competição por nutrientes entre a forrageira e a cultura acompanhante.

Neste ensaio foram testados 2 níveis de adubação :

Nível 1: Sem adubação.

Nivel 2: Com adubação.

A quantia de adubo utilizada foi 20 gramas de 05-15-10 por metro linear da forrageira equivalentes a $16,0 \mathrm{~kg} / \mathrm{ha}$ de $\mathrm{N}, 48,0 \mathrm{~kg} / \mathrm{ha}$ de $\mathrm{P}_{2} \mathrm{O}_{5}$ e $32,0 \mathrm{~kg} / \mathrm{ha}$ de $\mathrm{K}_{2} \mathrm{O}$.

\subsection{4 - Tratamentos adicionais}

Para se avaliar melhor o efeito da forrageira sobre o milho foram implantados 2 tratamentos adicionais com a cultura em cultivo exclusivo.

Estes tratamentos foram os seguintes:

Tratamento adicional 1: Cultura exclusiva com espaçamento de linhas equidistantes (SM1)

Tratamento adicional 2: Cultura exclusiva com espaçamento modificado (SM2).

\subsection{0 - Delineamento experimental}

O delineamento adotado foi o de parcelas subdivididas (split-plot). Os 8 tratamentos resultantes do fatorial $2 \times 4$ (combinação das épocas de semeadura da forrageira e níveis de adubação da gramínea) foram consideradas como subparcelas e o espaçamento do milho como parcelas com 4 repetições. O Quadro 2 mostra os 8 
tratamentos das subparcelas resultantes da combinação das quatro épocas de semeadura da B. brizantha com os dois niveis de adubação.

QUADRO 2 - Tratamentos das subparcelas, resultantes do fatorial 4 × 2 (combinação das épocas de semeadura x niveis de adubação).

\begin{tabular}{|c|c|c|}
\hline Tratamentos & $\begin{array}{l}\text { Época de semeadura da forra- } \\
\text { geira em dias após a semeadu- } \\
\text { ra do milho }\end{array}$ & Adubação \\
\hline $1(\mathrm{E} 1 \mathrm{~A})$ & 0 & COM \\
$2(\mathrm{E} 1 \mathrm{~S})$ & 0 & SEM \\
$3(\mathrm{E} 2 \mathrm{~A})$ & 21 & COM \\
$4(\mathrm{E} 2 \mathrm{~S})$ & 21 & SEM \\
$5(\mathrm{E} 3 \mathrm{~A})$ & 42 & COM \\
$6(\mathrm{E} 3 \mathrm{~S})$ & 42 & SEM \\
$7(\mathrm{E} 4 \mathrm{~A})$ & 63 & COM \\
$8(\mathrm{E} 4 \mathrm{~S})$ & 63 & SEM \\
\hline
\end{tabular}

Estes oito tratamentos, distribuidos nas subparcelas, foram testados sob os tratamentos de espaçamento do milho de "linhas equidistantes" e "modificado" conforme esquema de campo da Fig. 2. A distância entre a última linha de milho de uma parcela de espaçamento modificado para a primeira da parcela de espaçamento de linhas equidistantes é de $1,25 \mathrm{~m}$.

O esquema de análise de variância foi montado para avaliação em separado das variáveis relativas ao milho e as variáveis relativas à forrageira conforme quadros 3 e 4 . 


\section{BLOCO 1}

Espaçamento

\begin{tabular}{|c|c|}
\hline & $1-1,25 \mathrm{~m}$ \\
\hline modificado & SM2 E2S E1A E3A E4A E1S E3S E4S E2A \\
\hline
\end{tabular}

BLOCO 2

Espaçamento

modificado E4A E2S E3S E1A E2A SM2 E3A E1S E4S

1- $1.25 \mathrm{~m}$

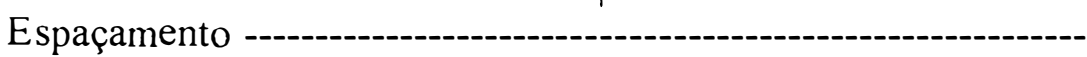
de linhas E1S ElA SMI E2A E4S E3S E4A E3A E2S

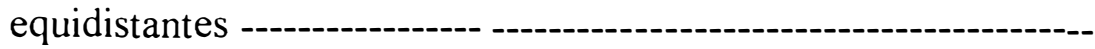

\section{BLOCO 3}

Espaçamento

de linhas

E1A E2A SM1 E3A E3S E4A E2S E1S E4S

equidistantes

$$
-1.25 \mathrm{~m}
$$

Espaçamento modificado

E2A E4S E1A E1S E2S E3A SM2 E4A E3S

\section{BLOCO 4}

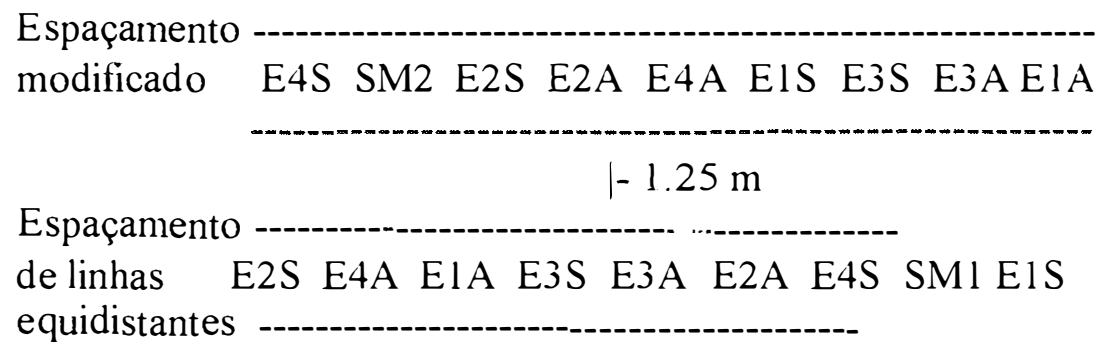

FIG. 2 - Esquema de campo de distribuição dos tratamentos. 
QUADRO 3 - Esquema de análise de variància para dados relativos ao milho.

\begin{tabular}{|c|c|}
\hline Causas de variação & Graus de liberdade \\
\hline Blocos & 3 \\
Espaçamento (Esp.) & 1 \\
Residuo (A) & 3 \\
\hline Parcela & 7 \\
\hline Tratamento & 7 \\
Esp. x Trat. & 7 \\
Residuo (B) & 42 \\
\hline Total & 63 \\
\hline
\end{tabular}

QUADRO 4 - Esquema de análise de variância para dados relativos a forrageira.

\begin{tabular}{|c|c|}
\hline Causas de variação & Graus de liberdade \\
\hline Blocos & 3 \\
Espaçamento (Esp.) & 1 \\
Residuo (A) & 3 \\
\hline Parcela & 7 \\
\hline Adubação (Ad.) & 1 \\
Época de semeadura (Ep.) & 3 \\
Ad. X Ep. & 3 \\
Ad. X Esp. & 1 \\
Ep. X Esp. & 3 \\
Ad. X Ep. X Esp. & 3 \\
Residuo (B) & 42 \\
\hline Total & 63 \\
\hline
\end{tabular}

\subsection{1 - Coleta de dados}

\subsection{1 - Coleta de dados do milho}

As variáveis avaliadas foram: produção total de matéria seca (planta inteira) aos 110 dias, produção de grãos, teor de matéria seca dos grãos e população de plantas.

A produção de matéria seca foi coletada sorteando-se ao acaso 2 amostras de $0,5 \mathrm{~m}$ lineares a $0,5 \mathrm{~m}$ da bordadura por parcela. As 2 amostras eram agrupadas em uma única amostra e então pesadas verde para posterior corte e secagem de uma 
sub - amostra em estufa a $65^{\circ} \mathrm{C}$ por 48 horas para determinação do teor de matéria seca. O valor do teor de matéria seca era então multiplicado pela produção de massa verde e tinha-se a produção de matéria seca da parcela.

A produção de grãos foi feito coletando - se toda a produção da área útil da parcela e posterior pesagem. A área útil da parcela foi considerada as 4 linhas centrais da parcela com 1 metro de bordadura entre as parcelas na linha de milho. Foi retirado uma amostra para determinação do teor de matéria seca em estufa a $65^{\circ} \mathrm{C}$ por 48 horas. Esta foi misturada com as amostras das demais parcelas e feita uma única determinação média para todas as parcelas.

A determinação da porcentagem de matéria seca dos grãos foi feito coletando - se uma amostra de cada parcela quatro dias após a colheita e secagem em estufa a $65^{\circ} \mathrm{C}$ por 48 horas.

A determinação da população de plantas foi feita fazendo - se a contagem de plantas em duas amostragens de 0,50 metros lineares na área útil da parcela. $\mathrm{O}$ valor da parcela foi considerado a média das duas amostragens.

\subsection{2 - Coleta dos dados do capim}

As variáveis avaliadas foram: população de plantas aos 21 e 42 dias da semeadura, produção de matéria seca após 2 meses da colheita do milho e 7 meses após a colheita do milho e porcentagem de cobertura do solo após 2 meses da colheita do milho e 7 meses após a colheita do milho. 
A população de plantas aos 21 e 42 dias foi avaliado amostrando - se ao acaso 1,0 metro linear de $50 \%$ das linhas de forrageira da parcela e contagem do número de plantas.

A avaliação da produção de matéria seca da parcela foi feito após corte da área útil da parcela, separação de plantas invasoras, pesagem do material verde total da parcela com a retirada de uma amostra para determinação do teor de matéria seca em estufa a $65^{\circ} \mathrm{C}$ por 48 horas. A produção da parcela era dado pela produção de massa verde multiplicado pelo teor de matéria seca.

A área útil da parcela foi considerada as 6 linhas internas da forrageira e deixando-se 1,0 metro de bordadura entre as parcelas sendo colhido 5 metros lineares internos da parcela.

O corte realizado após 2 meses da colheita do milho foi manual e o realizado após 7 meses foi ceifadora mecanizada.

A avaliação da porcentagem de cobertura do solo foi feito através média das observações visuais de très avaliadores após prévia calibração. 


\section{4 - RESULTADOS E DISCUSSÃO}

\section{1 - Efeitos dos tratamentos sobre a cultura do milho}

\subsection{1 - População de plantas do milho nos diferentes tratamentos estu- dados}

A população de plantas de milho nos tratamentos de plantio estudados podem ser vistos na tabela 1 e 2 .

Tabela 1 - População de plantas de milho em dois espaçamentos (plantas/ha).

\begin{tabular}{|c|c|}
\hline Equidistantes & 52.000 \\
\hline Modificado & 48.667 \\
\hline
\end{tabular}

ns $(\mathrm{P}<5 \%) ; \mathrm{DMS}=19.642,64$ plantas/ha; $\mathrm{CV}=17,34 \%$

Tabela 2 - Efeito da época de semeadura do capim em dias após a semeadura do milho e adubação sobre a populaçào do milho (plantas/ha).

\begin{tabular}{|c|c|c|}
\hline \multirow[t]{2}{*}{0} & $\mathrm{COM}$ & 40.000 \\
\hline & SEM & 46.000 \\
\hline \multirow[t]{2}{*}{21} & $\mathrm{COM}$ & 60.000 \\
\hline & SEM & 51.000 \\
\hline \multirow[t]{2}{*}{42} & $C C_{\ldots 1}$ & 41.000 \\
\hline & SEM & 50.000 \\
\hline \multirow[t]{2}{*}{63} & $\mathrm{COM}$ & 48.000 \\
\hline & SEM & 60.000 \\
\hline Milho exclusivo & -........ & 57.000 \\
\hline
\end{tabular}

ns $(\mathrm{P}<5 \%) ; \mathrm{DMS}=30.400,99$ plantas/ha; $\mathrm{CV}=37,11 \%$

Foi feito avaliação e análise da população de plantas de milho e esta nào diferiu estatisticamente entre os tratamentos, porém a população média de plantas de 
milho obtida , 50.333,32 plantas/ha, foi superior a planejada no inicio do experimento, 40.000 plantas/ha. Este fato ocorreu devido as condições climáticas ocorridas na sua implantação, onde a ocorrència de um "veranico", prejudicou a germinação da cultura. Foi feito um replantio para corrigir falhas na população de plantas de milho e após esta não foi feito raleação, pois seria realizada tardiamente o que prejudicaria o sistema radicular do milho.

\subsection{2-Efeitos dos tratamentos sobre a produção de matéria seca do milho.}

O efeito da época de semeadura e adubação sobre a produção de matéria seca (planta inteira) do milho pode ser visto na tabela 3.

Tabela 3 - Efeito dos época de semeadura e adubação do capim sobre a produção de matéria seca (planta inteira) do milho(t/ha).

\begin{tabular}{|c|c|c|}
\hline \multirow[t]{2}{*}{0} & $\mathrm{COM}$ & 14,37 \\
\hline & SEM & 16,10 \\
\hline \multirow[t]{2}{*}{21} & COM & 14,72 \\
\hline & SEM & 15,27 \\
\hline \multirow[t]{2}{*}{42} & COM & 14,00 \\
\hline & SEM & 15,95 \\
\hline \multirow[t]{2}{*}{63} & COM & 12,68 \\
\hline & SEM & 15,78 \\
\hline Milho exclusivo & 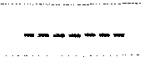 & 19,46 \\
\hline
\end{tabular}

ns $(\mathrm{P}<5 \%) ; \mathrm{DMS}=8.652,77 \mathrm{~kg} / \mathrm{ha} ; \mathrm{CV}=34,58 \%$

A produção de matéria seca do milho não foi significativamente afetada pelas épocas de semeadura do capim e sua adubação. Este fato ocorreu devido ao capim apresentar-se pouco desenvolvido durante o crescimento do cereal e portanto não afetando desenvolvimento deste. Embora não se tenha observado diferença estatística, observou-se que a produção para o tratamento de milho exclusivo foi maior 
que aqueles onde semeou-se o capim, o que indicaria que houve tendència da presença do capim prejudicar a produção de matéria seca do milho.

A produção do milho teria sido pouco ou nada prejudicada pela presença do capim, semeado nas diferentes épocas, pois mesmo na sua semeadura mais precoce, na mesma data do plantio do milho, estaria pouco desenvolvido, não apresentando grande competição com o milho.

As forrageiras tropicais apresentam desenvolvimento inicial lento. VIEIRA (1974) encontrou frequência de ocorrència de Brachiaria decumbens de 51,18\% aos 54 dias após sua germinação, com o restante da área sem cobertura ou com plantas daninhas.

Quando o capim apresentou maior desenvolvimento, o milho já possuia um porte no qual seria pouco afetado pela sua presença. BLANCO (1972) mostrou que a época mais crítica de competição para o milho é até os 45 dias, pois depois desta época o milho é pouco afetado por presença de invasoras.

O milho, por estas caracteristicas, tem sido uma cultura muito utilizada em sistemas de consórcio principalmente com a cultura do feijão onde é pouco ou quase nada afetado pela presença da leguminosa. Em sistemas de consórcio onde se utiliza o milho, este normalmente é a planta dominante e a que sofre menor competição (GERA I DI, 1983), sendo uma planta que se presta bem a este tipo de prática (DIAS FILHO, 1990). VIEIRA (1982) relata que nas consorciações de milho e feijão, esta cultura, nas densidades comumente usadas da leguminosa, não afeta a produção de milho. SANTA-CECÍLlA (1978) também não encontrou efeito depressivo sobre a produção de milho mesmo quando o feijão foi plantado na linha de milho. 
A competição entre o capim e o milho só seria acentuada prejudicando a cultura quando água e nutrientes tiverem déficit acentuado ou seja em solos de baixa fertilidade ou na ocorrència de "stress" hidrico. Condições estas não observadas no presente trabalho.

O fato de não ter se encontrado diferença significativa entre as produções de matéria seca de milho nos espaçamentos utilizados, (Tabela 4), foi devido a que durante o seu crescimento as exigèncias por água, luz e nutrientes são menores e o milho foi cortado antes de sua completa maturação, periodo de maior exigència, além do que as condições climáticas e de fertilidade do solo foram muito boas durante o período experimental.

A fertilidade do solo e condições climáticas adequadas durante o crescimento propiciaram uma menor competição intra e inter especifica para a cultura do milho.

Tabela 4 - Efeito de espaçamento do milho sobre a produção de milho $(\mathrm{kg} / \mathrm{ha}$ de matéria seca).

\begin{tabular}{|c|c|}
\hline Linhas equidistantes & 15,81 \\
\hline Linhas modificadas & 14,93 \\
\hline
\end{tabular}

n.S. $(\mathrm{P}<5 \%) ;$ D.M.S. $=1.829,13 ;$ C.V. $=5,29 \%$

\subsection{3 - Efeitos dos tratamentos sobre a produção de grãos do milho.}

A produção de grãos de milho (kg/ha), corrigidos para $13 \%$ de umidade, não foi afetada por época de semeadura e adubação do capim porém foi afetada significativamente pelo espaçamento. Os resultados podem ser vistos na tabela 5 e 6 . 
Tabela 5 - Efeito de espaçamento do milho sobre a produção de milho $(\mathrm{kg} / \mathrm{ha}$ de gràos).

\begin{tabular}{|c|c|}
\hline Linhas equidistantes & $7.244 \mathrm{a}$ \\
\hline Linhas modificadas & $6.356 \mathrm{~b}$ \\
\hline
\end{tabular}

D.M.S. $=588,06 ;$ C.V. $=3,84 \%$

As produções de milho obtidas neste experimento foram próximas as produzidas pelo AG-106 em testes regionais de avaliaçào de cultivares realizados pelo Instituto Agronômico de Campinas e Coordenadoria de Assistência Técnica Integral em vários locais do estado (IAC, 1991).

As diferenças entre as produções de gràos para espaçamento foram significativas a 5\% e 1\%. Este fato se deveu a uma maior competiçào intraespecificas entre as plantas de milho no espaçamento modificado. Apesar desta competição nào ter afetado significativamente o crescimento e produçào de forragem pela cultura, afetou a produçào de gràos do milho.

Este efeito ocorreu devido a planta de milho ser uma cultura bastante competitiva e o espaçamento modificado com linhas duplas aumentar a concorrència intraespecifica devido a maior proximidade das plantas de milho. Como no período de florescimento e granaçào as exigèncias por água, luz e nutrientes é maior, houve prejuizo na produçào de gràos.

LOPEZ \& MAESTK ( 1983 ) demonstraram que o indice de área foliar (IAF) do milho é máximo ao redor de 92 dias após a emergència sendo maior a exigència em luz neste período. Em experimento para avaliar extraçào de nutrientes pela cultura do milho, ANDRADE et al. (1977) encontrou máximas quantidades de nutrientes nas plantas entre 80 a 120 dias para a maioria dos nutrientes. 
AIDAR \& VIEIRA, 1979 trabalhando com consórcio de milho e feijão com 3 populações de plantas; 20, 40 e 60.000 plantas/ha; observou que a produtividade de milho não foi afetada pela presença do feijão nas diferentes populações mas foi afetada pela maior competição intraespecífica quando se aumentou a sua densidade de plantio.

A produção de grãos não foi afetada pela época de semeadura e adubação do capim. Este fato pode ser explicado pelos motivos expostos em 4.2.2.

Os resultados obtidos discordam daqueles encontrado por MACEDO \& ZIMMER, 1990 trabalhando com milho e Brachiaria brizantha em cultivo associado. Estes Autores encontraram efeito significativo da presença do capim afetando a produção do milho. No trabalho realizado por estes autores foi semeado o milho e o capim em duas épocas do ano, janeiro e outubro.

O efeito depressivo maior da forragem ocorreu quando se efetuou a semeadura em época mais desfavorável ao milho, janeiro, em relação a época mais propícia, outubro. As diferenças de produção foram de 54\% para o plantio de janeiro, 1362 e $2097 \mathrm{~kg} / \mathrm{ha}$ de grãos para os tratamentos com e sem capim respectivamente. Para o plantio em outubro onde as condições foram melhores esta diferença caiu para $26 \%$, sendo as produções obtidas de 2992 e 3734 kg/ha de grãos com e sem o capim.

Quando as condições foram favoráveis, outubro, a produç̃̃ $=$ do milho com o capim foi maior que o plantio exclusivo de milho em época desfavorável, 2992 $\mathrm{kg} / \mathrm{ha}$ e $2097 \mathrm{~kg} / \mathrm{ha}$ respectivamente. Estes dados sugerem que o consórcio é mais afetado pelas condições climáticas que pela competição entre plantas intercaladas.

Os autores encontraram efeito depressivo do capim quando taxas de semeadura utilizadas eram superiores a $1,50 \mathrm{~kg} / \mathrm{ha}$ de sementes puras viáveis porem neste 
trabalho apesar de ter sido utilizadas superior a $1.50 \mathrm{~kg} / \mathrm{ha} ; 5,5$; o milho não foi afetado pela competição com o capim. Este efeito pode ser explicado devido as melhores condições de solo e o clima favorável durante o crescimento e maturação da cultura ocorrido neste experimento. O que pode ser comprovado pelas diferenças de produções de milho obtidas nos dois trabalhos.

Tabela 6 - Efeito dos época e adubação do capim sobre a produção de milho $(\mathrm{kg} / \mathrm{ha}$ de grãos corrigidos para $13 \%$ de umidade).

\begin{tabular}{|c|c|c|}
\hline \multirow{2}{*}{ Época 1} & COM & 7.179 \\
\hline & SEM & 6.472 \\
\hline \multirow[t]{2}{*}{ Época 2} & $\mathrm{COM}$ & 6.956 \\
\hline & SEM & 6.782 \\
\hline \multirow[t]{2}{*}{ Época 3} & $\mathrm{COM}$ & 7.362 \\
\hline & SEM & 6.626 \\
\hline \multirow[t]{2}{*}{ Epoca 4} & $\mathrm{COM}$ & 6.674 \\
\hline & SEM & 6.384 \\
\hline Milho exclusivo & - & 6.832 \\
\hline
\end{tabular}

SHELTON \& HUMPHREYS, 1972 encontraram efeito depressivo da época de semeadura de estilosantes intercalado a cultura de arroz em sua produção. O milho é uma planta mais competitiva que o arroz apresentando rápido crescimento e agressividade. DIAS FILHO, 1990 recomendou esta cultura para este tipo de prática, afirmando ser esta mais viável que o arroz. Este mesmo autor recomenda a semeadura do capim na mesma época do cereal e podendo esta ser na linha ou no sulco da cultura.

O capim tem um crescimento inicial lento e demorado. No caso de B. decumbens demorou até 54 dias para cobrir o solo em 56\% (VIEIRA, 1974). BLANCO, 1972 mostrou que a época mais crítica de competição para o milho como 
sendo até os 45 dias, pois depois desta época o milho é pouco afetado por de invasoras. Sendo assim a competição entre o capim e o milho só será acentuada prejudicando a cultura quando água e nutrientes tiverem déficit acentuado ou seja em solos de baixa fertilidade ou na ocorrência de "stress" hídrico.

\section{2 - Efeitos dos tratamentos sobre o capim}

\subsection{1 - Efeitos dos tratamentos sobre a população do capim}

A população de plantas do capim foi observada em dois periodos: aos 21 e 42 dias após o plantio do capim. Aos 21 dias após a semeadura do capim não houve efeito significativo sobre a população de plantas do capim para os tratamentos espaçamento do milho e adubação porém houve efeito significativo da época de semeadura do capim como pode ser visto na tabela 7 .

Quando se plantou o capim na época 1 houve uma diferença significativa em relação as demais épocas. Este fato não se deveu aos tratamentos empregados. A causa mais provável desta menor população de plantas foi a ausência de chuvas logo

após a instalação do experimento que prejudicou tant", a germinação do capim quanto do milho. 
Tabela 7 - Efeito de espaçamento do milho, época de semeadura e adubação do capim sobre a população de plantas do capim aos 21 dias (plantas $/ \mathrm{m}^{2}$ ).

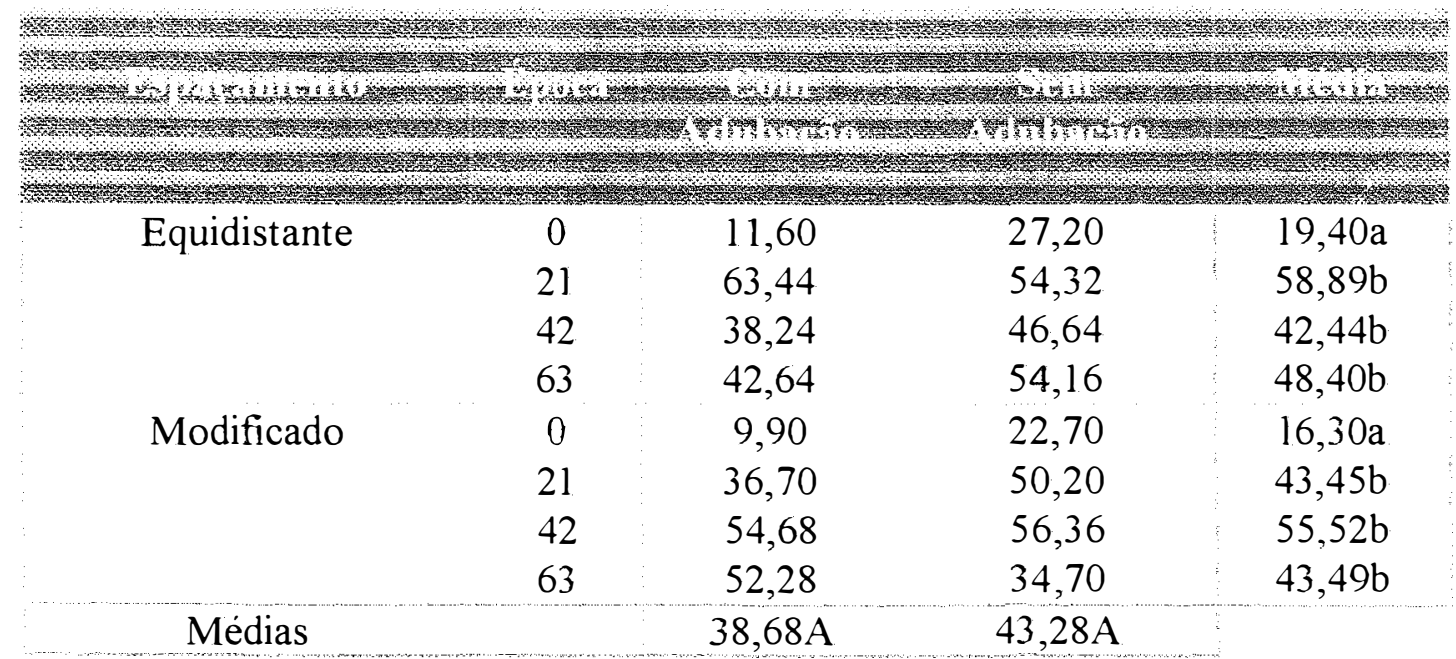

Médias seguidas de letras distintas na linha ou coluna diferem entre si a $5 \%$ D.M.S. $(5 \%)=18,76$ plantas $/ \mathrm{m}^{2} ;$ Média $=40,95$ plantas $/ \mathrm{m}^{2} ;$ C.V. $=34,20 \%$

Houve uma tendència, apesar de não ter ocorrido diferença estatística, de menor germinação nas parcelas adubadas da época 1 apesar de este efeito desaparecer aos 42 dias (Tabela 8). Este fato pode ter sido devido a baixa umidade do solo em associação com o efeito higroscópico dos adubos empregados que prejudicou parcialmente a germinação

ZIMMER, 1983 afirma que a aplicação de adubos em sulcos, especialmente quando este fica próximos as sementes, podem resultar em reduções na germinação devido a absorção da água em torno da semente pelo adubo que pode provocar queimaduras nos tecidos das mesmas. Isto se acentua quando houver pouca umidade no solo.

A cultura exerceu pouco efeito sobre a germinação e população do capim sendo que a adubação e espaçamento não tiveram efeito significativo sobre a cultura. Este resultado coincide com os obtidos por HAGGAR (1972) onde o milho e outras 
culturas acompanhantes não afetaram a população de plantas de Andropogon gaynus aos 4 e 11 meses após a sua semeadura intercalar a cultura acompanhante.

Os resultados obtidos confirmam uma boa população inicial do capim, media de 40,95 plantas $/ \mathrm{m}^{2}$, superiores a valores considerados como ideais por ZIMMER (1983) de 10 a 20 planta $/ \mathrm{m}^{2}$ e DIAS FILHO (1990) que recomenda 15 plantas $/ \mathrm{m}^{2}$ como sendo uma população inicial aceitável. Apesar de prejudicada ainda assim a população de plantas no tratamento onde se semeou o capim na mesma época do milho, 10,75 e 24,95 para os tratamentos adubado e não adubado respectivamente, podem ser considerados satisfatórios.

Quando se analisou a população de plantas do capim aos 42 dias não encontrou-se efeito significativo dos tratamentos espaçamento e adubação nos resultados. O fator época foi significativo como pode ser visto na tabela 8.

Tabela 8 - Efeito de espaçamento do milho, época de semeadura e adubação do capim sobre a população de plantas do capim aos 42 dias (plantas $/ \mathrm{m}^{2}$ ).

\begin{tabular}{|c|c|c|c|c|c|}
\hline \multirow[t]{2}{*}{ Equidistante } & Com & 23,20 & 59,12 & 37,76 & 41,52 \\
\hline & Sem & 27,60 & 52,48 & 38,64 & 48,72 \\
\hline \multirow[t]{2}{*}{ Modificado } & $\overline{C o m}$ & $\overline{25,70}$ & 67,44 & 41,12 & 48,20 \\
\hline & Sem & 28,40 & 53,40 & 55,20 & 32,50 \\
\hline \multicolumn{2}{|c|}{ Média } & $26,22 \mathrm{a}$ & $58,11 \mathrm{c}$ & $43,33 b c$ & $42,73 b c$ \\
\hline
\end{tabular}

Média seguidas de letras distintas na linha ou coluna erem entre si a $5 \%$ D.M.S. $(5 \%)=18,76$ plantas $/ \mathrm{m}^{2} ;$ Média $=40,95$ plantas $/ \mathrm{m}^{2} ;$ C.V. $=34,20 \%$

A época 1, quando se semeou o capim na mesma época que o milho, apresentou uma população de plantas significativamente menor, o que pode ser justificado pelos motivos apontados para população aos 21 dias. A tedência de um maior número de plantas $/ \mathrm{m}^{2}$ apresentado pela época 2 em relação as épocas 3 e 4 deve-se 
uma maior competição da cultura do milho com o capim afetando o seu estabelecimento em semeaduras mais atrasadas. Quando foi feito a avaliação aos 42 dias após a semeadura do capim, o milho já estava com 84 e 105 dias de semeado para nos tratamentos época 3 e época 4, respectivamente. Nesta fase o milho apresenta seu índice de área foliar máximo ocorrendo a maior intensidade de sombreamento do capim (Lopes \& Maestri, 1973 citados por CORSI, 1986) além de uma maior competição por nutrientes como demonstraram ANDRADE et al., 1977.

SHELTON \& HUMPHREY, 1972 testando a implantação de estilosantes intercalar a cultura do arroz em 3 épocas: 0, 31 e 60 dias após semeadura da cultura; observou um maior prejuizo da leguminosa a medida que seu plantio foi retardado. A população de estilosantes (plantas/m2) foram 24,$5 ; 15$ e 6,5 respectivamente para os tratamentos com semeadura aos $0 ; 31$ e 60 dias após o plantio do arroz.

\subsection{2 - Efeitos dos tratamentos sobre a produção de matéria seca capim}

A produção de matéria seca do capim foi avaliado aos 2 e 7 meses após a colheita do milho. Aos 2 meses a B. brizantha sofreu efeito significativo do espaçamento do milho empregado e da época de semeadura da forrageira. A adubação não teve efeito significativo (tabela 9).

A produção de matéria seca rignificativamente maior para o espaçamento modificado pois a disposição das plantas de milho neste espaçamento permitia uma menor competição, entre as espécies estudadas, por água, nutrientes e principalmente luz.

As forrageiras tropicais são muito sensiveis ao sombreamento (LUDLOW,1978) e a medida que este aumenta, a forrageira é mais prejudicada pela 
competição por água e nutrientes (WILSON, 1978). Em trabalhos de consorciação de milho e feijão tem-se como uma das causas do menor rendimento da leguminosa é o sombreamento (VIEIRA, 1982; SANTA-CECÍlLA, 1978).

Tabela 9 - Efeito de espaçamento do milho, época de semeadura e adubação do capim sobre a produção de matéria seca do capim aos 2 meses após a colheita do milho $(\mathrm{kg} / \mathrm{ha})$.

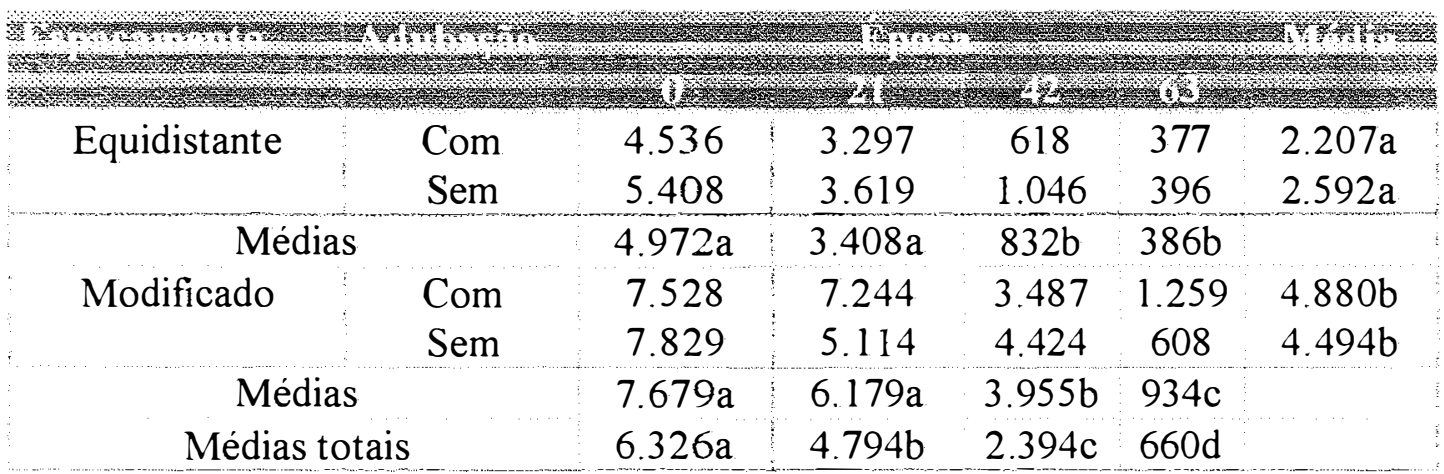

Médias seguidas de letras distintas na mesma linha ou coluna diferem entre si a $5 \%$ Média $=3.543,20 \mathrm{~kg} / \mathrm{ha}$

Em trabalho realizado em várias regiões do Paraná (IAPAR, 1980) onde o feijão foi semeado em cultura exclusiva, intercalar ao milho e em 2 sistemas de plantio em faixa, obteve-se melhores produções de feijão quando este foi semeado nos sistemas em faixas.

A produção do capim foi diminuindo a medida que se atrasou sua semeadura em relação ao plantio do milho. Este fato pode ser explicado pelo maior favorecimento da cultura na competição por água, luz e nutrientes a medida que se atrasava o plantio da forragura. Este dados coincidem com os obtidos por SHELT N \& HUMPHREYS, 1972.

Quando se semeou o capim intercalar ao milho em espaçamento equidistante, nas épocas 1 e 2 , não houve diferença significativa na produção de forragem. Este fato se deve demonstra que o milho em seu desenvolvimento inicial não afeta o capim sendo a competição mais acentuada a partir de 45 dias (BLANCO 1972). 
Quando se observou as épocas 3 e 4, estas não apresentaram diferença entre si porém tiveram sua produção diminuida significativamente em relação as épocas 1 e 2. Este fato demonstra que até 21 dias da semeadura do milho, o capim tem melhor produção de matéria seca favorecendo seu estabelecimento.

No espaçamento modificado do milho, as épocas 1 e 2 não apresentaram diferença estatística entre si porém foi significativamente maior que a época 3 e esta por sua vez foi maior que a época 4 . Neste tipo de arranjamento de plantas de milho como a competição é menos acentuada para o capim, a época 3 obteve melhor resultado que a época 4 , que mesmo neste tipo de espaçamento foi bem afetado pela competição com o milho, devido a sua implantação quando este apresentava-se já desenvolvido.

A adubação não apresentou efeito significativo. Este fato pode ser explicado pela boa fertilidade inicial do solo que apresentava teores de adequados para o estabelecimento do capim. O nível de fósforo encontrado no solo; 15,5 ppm P (resina); é próximo a aqueles encontrados por CORREIA, 1991 como níveis críticos para $80 \%$ da produção máxima de B. brizantha de 15 a 22 ppm em experimento em vaso e 21,8 ppm a campo. WERNER, 1986 não recomenda adubação potássica para solos com ‘ 'oores de potássio superiores a $0,12 \mathrm{meq} . / 100 \mathrm{~cm}^{3}$ de terra. Vível este inferior ao encontrado no solo trabalhado que era de 0,24 meq. $/ 100 \mathrm{~cm}^{3}$.

PEREIRA (1986) comentando sobre a capacidade das branquiárias de vegetar em solos com baixos teores de fósforo disponíveis, cita que estas gramíneas não requerem mais do que $45 \mathrm{~kg} / \mathrm{ha}$ de $\mathrm{P}_{2} \mathrm{O}_{5}$ para obter-se boas produções. O nível crítico 
externo para B. humidicola foi de $10,0 \mathrm{~kg} / \mathrm{ha}$ de $\mathrm{P}_{2} \mathrm{O}_{5}$ e para Andropogon gayanus, B. decumbens e B. brizantha o nível crítico chega a $20 \mathrm{~kg} / \mathrm{ha}$ de $\mathrm{P}_{2} \mathrm{O}_{5}$.

O efeito do espaçamento do milho sobre a produção de matéria seca do capim aos 7 meses foi significativo e sofreu interação com adubação conforme pode ser visto na tabela 10 .

Tabela 10 - Efeito de espaçamento de plantio do milho e adubação do capim sobre a produção de matéria seca do capim aos 7 meses após a colheita do milho $(\mathrm{kg} / \mathrm{ha})$.

\begin{tabular}{|c|c|c|}
\hline Com & $2.133,33 \mathrm{aA}$ & $1.722,55 \mathrm{bA}$ \\
\hline Sem & $2.043,14 \mathrm{aA}$ & $1.126,26 \mathrm{bB}$ \\
\hline
\end{tabular}

Médias seguidas de letras distintas minúscula na mesma linha ou maiúscu mesma coluna diferem entre si a $5 \%$.

Média $=1.756,32 \mathrm{~kg} / \mathrm{ha} ;$ C.V. $=14,56 \%$ (espaçamento) e 26,61\% (adubação).

A produção foi maior para o espaçamento equidistante tanto para os tratamentos adubados como os não adubados. Este fato seria explicado por este espaçamento possuir um melhor distribuição espacial das linhas do capim sobre o solo, com espaçamento de $0,80 \mathrm{~m}$ entre uma linha e outra da forrageira onde antes existia o milho, ocorrendo menor infestação de plantas invasoras. Este seria a causa da menor produção do espaçamento modificado que apresentou uma maior infestação de plantas invasoras nas linhas onde anteriormente encontrava-se o milho. Este espaço de 1,30m entre duas linhas do capim, não foi totalmente ocupado, pois a B. brizantha, tem hábito de crescimento cespitoso.

VIEIRA, 1974 encontrou produções semelhantes de B. decumbens quando utilizou espaçamentos de $0,40 \mathrm{~m}$ e $0,80 \mathrm{~m}$ mas estes espaçamentos tiveram produções 
superiores aos espaçamentos de $1,20 \mathrm{~m}$ e 1,40m. O Autor justifica esta melhor produção a uma menor presença de invasoras nos espaçamentos menores.

A adubação apresentou resultado significativo para produção de matéria seca aos 7 meses apenas o espaçamento modificado (Tabela 10). Este fato seria explicado por maior concorrència com invasoras afetaria a utilização dos nutrientes e portanto prejudicando a produção do tratamento não adubado.

BLANCO (1972) estudando a competição de milho com plantas invasoras encontrou efeito destas sobre o estado nutricional das plantas de milho, para os níveis de nitrogènio e potássio na composição da planta.

HUMPHREYS (1987) relata que o poder de competição de plantas forrageiras com plantas daninhas é aumentad o com a utilização de fertilizantes. A utilização de adubação com nitrogènio, fósforo e potássio aumentou de $70 \%$ para $94 \%$ da porcentagem em peso de C. ciliaris, em relação ao peso total da produção de uma pastagem, onde foram testados 3 tipos de preparo de solo, em detrimento das plantas invasoras.

O efeito das épocas de semeadura da B. brizantha em relação ao plantio de milho sobre a produção de matéria seca do capim aos 7 meses após a colheita do milho pode ser visto na tabela 11

Tabela 11 - Efeito da épcéa de semeadura do capim sobre a produção de matéria seca do capim (kg/ha) aos 7 meses após a colheita do milho.

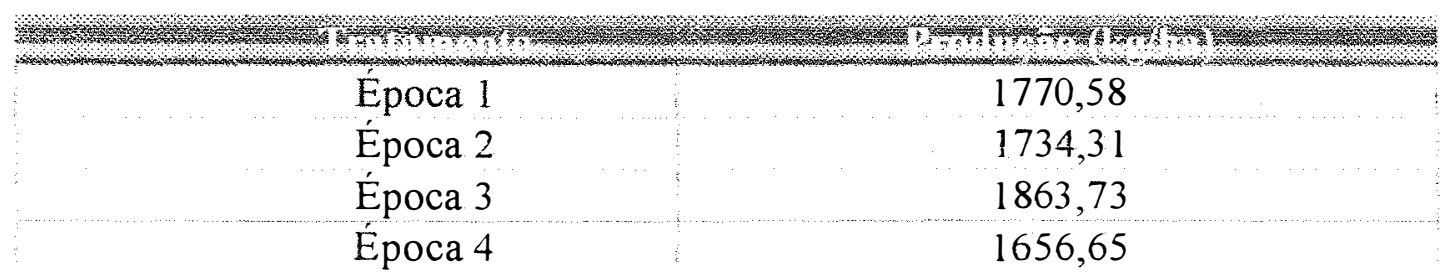

n.s. $(P<5 \%) ;$ Média $=1.756,32 \mathrm{~kg} / \mathrm{ha} ; \mathrm{C} . \mathrm{V} .=26,61 \%$ (época) 
As épocas de semeadura do capim em relação ao plantio do milho não influenciaram a produção do capim aos 7 meses após a colheita do milho. Este fato seria explicado por um bom estabelecimento inicial (plantas do capim'm2) do capim em todos os tratamentos apesar de ter existido diferenças ocorridas entre eles. Como o milho já não estava mais na área, os fatores que afetaram o capim foram iguais para todas as épocas.

HAGGAR, 1972 trabalhando com várias culturas acompanhantes encontrou um efeito depressivo da cultura sobre a forrageira quando avaliou a produção de matéria seca no ano de estabelecimento da forragem. No segundo ano do trabalho, quando já não ocorria a competição das culturas, as produções de matéria seca se igualaram ao tratamento onde o capim foi plantado em cultivo exclusivo.

KELLY (1972) trabalhando com green panic e siratro, estabelecido com 2 cultivares de sorgo como cultura acompanhante, encontrou efeito depressivo da cultura sobre população de plantas do capim e da leguminosa no primeiro ano de estabelecimento da pastagem, mas no segundo ano ocorreu um aumento significativo da população de plantas do capim, onde esta dobrou em relação ao primeiro ano.

\subsection{3 - Efeitos dos tratamentos sobre a porcentagem de cobertura do solo pelo capim.}

Os efeitos dos tratamentos sobre a porcentagem de cobertura do solo pelo capim foi medido em duas épocas: 2 e 7 meses após a colheita do milho. O efeito de espaçamento e época sobre a porcentagem de cobertura do solo aos 2 meses podem ser vistos na tabela 12 . 
Tabela 12 - Efeito de espaçamento do milho e época de semeadura capim sobre a porcentagem de cobertura do solo pelo capim aos 2 meses após a colheita do milho(\%).

\begin{tabular}{|c|c|c|c|c|}
\hline Equidistante & $71,20 \mathrm{aA}$ & $62,50 a \mathrm{~A}$ & $24,58 \mathrm{bB}$ & $12,92_{\mathrm{a}}^{\mathrm{c}} \mathrm{A}$ \\
\hline Modificado & $74,37 \mathrm{aA}$ & $69,79 \mathrm{aA}$ & $62,50 \mathrm{aA}$ & $26,04 \mathrm{bA}$ \\
\hline
\end{tabular}

Médias seguidas de letras distintas minúscula na mesma linha ou maiúscula na mesma coluna diferem entre si a $5 \%$

Média $=50,49 \% ; C . V .=8,05 \%$ (espaçamento) e $21,32 \%$ (época)

O espaçamento apresentou efeito significativo sobre a cobertura de solo apenas na época 3. Este fato seria devido a menor competição por água, nutrientes e principalmente luz no espaçamento modificado que favoreceu uma maior produção do capim (Tabela 9) e conseqüentemente uma maior cobertura do solo.

No espaçamento equidistante, a disposição das plantas de milho no campo, promovia um maior sombreamento da forrageira e quando esta era semeada após 42 dias da semeadura do milho, este já apresentava porte elevado na fase de crescimento do capim prejudicando seu desenvolvimento, o que já não ocorria nas épocas 1 e 2 .

$\mathrm{Na}$ época 4, apesar de o tratamento com espaçamento equidistante, ter menor porcentagem de cobertura do solo que o espaçamento modificado, esta não foi significativa, pois o efeito de época seria mais intenso mascarando seu resultado.

Estes resultados concordam com dados apresentados por BLANCO (1972); IAPAR (1980); LUDLOW (1978); SAN ${ }^{-1-C E C I ́ L I A ~(1978) ; ~ S H E L T O N ~ \& ~}$ HUMPHREYS (1972); VIEIRA (1982); WILSON(1978).

O efeito da adubação sobre a porcentagem de cobertura do solo, 2 meses após a colheita do milho, pode ser vistos na tabela 13. A adubação não afetou a porcentagem de cobertura do solo do capim. 
Tabela 13 - Efeito da adubação do capim sobre a porcentagem de cobertura do solo do capim aos 2 meses após a colheita do milho (\%).

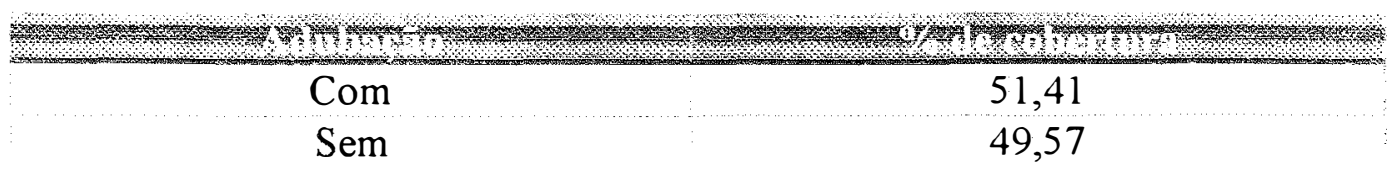

n.s. $(\mathrm{P}<5 \%)$; Média $=50,49 \%$; C.V. $=21,32 \%$

A não ocorrência de efeito da adubação seria explicado pelo fato do trabalho ter sido instalado em um solo de boa fertilidade além do capim utilizada ser de média exigência em fertilidade do solo. Estes resultados concordam com CORREIA (1991); PEREIRA (1986) e WERNER (1986).

O efeito de espaçamento sobre a porcentagem de cobertura do solo do capim aos 7 meses após a colheita do milho podem ser vistos na tabela 14 . O espaçamento equidistante apresentou uma maior cobertura do solo aos 7 meses após a colheita do milho.

Tabela 14 - Efeito do espaçamento do milho sobre a porcentagem de cobertura do solo do capim aos 7 meses após a colheita do milho (\%).

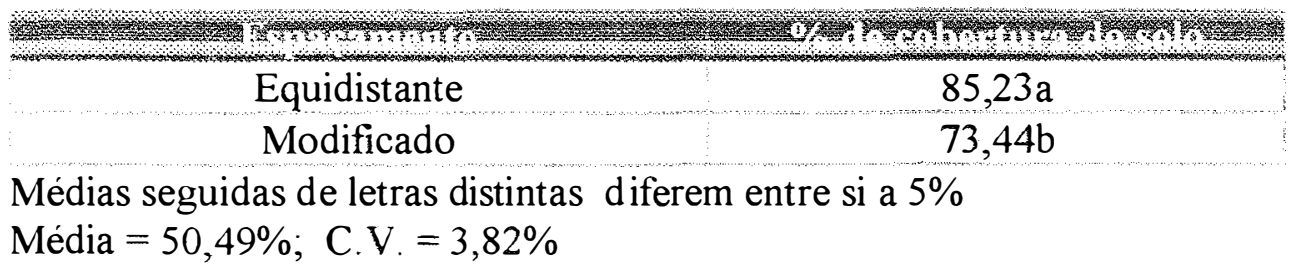

A melhor cobertura do solo pelo capim quando o milho foi plantado no espaçamento equidistaıe seria causado por uma melhor distribuição das plantas to capim no campo, após a colheita do milho, ficando as linhas deste distanciadas $0,80 \mathrm{~m}$ uma da outra no local onde antes existia a linha de milho em contraposição ao espaçamento equidistante, onde esta distancia era de 1,30m. Este maior espaço entre as linhas do capim favoreceu a ocorrência de invasoras que prejudicou o crescimento do capim e sua cobertura do solo. 
Estes resultados concordam com dados apresentados por BLANCO (1972); IAPAR (1980); LUDLOW (1978); SANTA-CECÍLIA (1978); SHELTON \& HUMPHREYS (1972); VIEIRA (1974); VIEIRA (1982) e WILSON (1978).

Os efeitos de época de semeadura e adubação do capim sobre a cobertura do solo aos 7 meses pode ser vista na tabela 15 .

Tabela 15 - Efeito da época de semeadura e adubação do capim sobre a porcentagem de cobertura do solo do capim aos $z$ meses após a colheita do milho (\%).

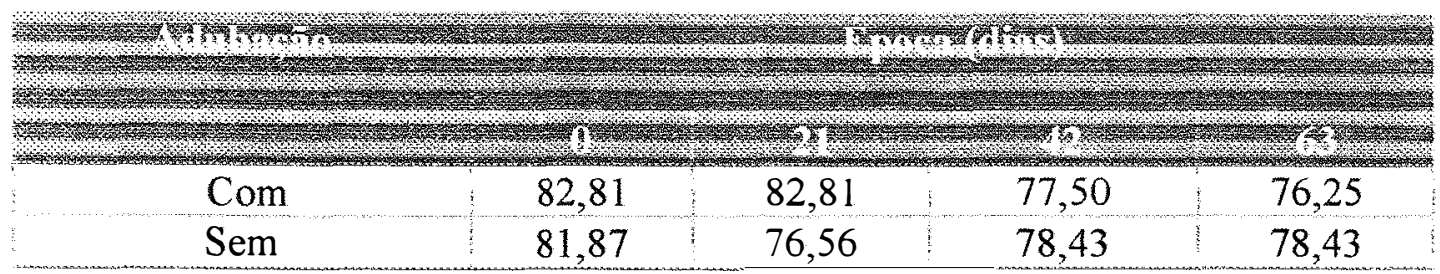

n.s. $(\mathrm{P}<5 \%) ;$ Média $=50,49 \% ; \mathrm{C} . \mathrm{V} .=8,55 \%$

A adubação e a época de semeadura do capim não apresentaram efeito significativo sobre a porcentagem de cobertura do solo do capim aos 7 meses após a colheita do milho.

A não ocorrência de efeito da época de semeadura do capim sobre esta variável seria devido a ausência de concorrência do capim com o milho. A presença do cereal e seu estágio de crescimento nas diferentes épocas é que seria a principal causa de competição com o capim e na ausência deste, após sua colheita, a rebrota não foi afetada e todas as épocas tiveram crescimento semelhante

Diferente dos resultados obtidos para produção de matéria seca do capim aos 7 meses após a colheita do milho, onde observou-se diferença significativa para o espaçamento modificado com e sem adubação, esta diferença não foi observada para porcentagem de cobertura de solo. Este resultado poderia ser explicado pelo fato de 
o tratamento sem adubo ter uma quantidade menor de matéria seca (folhas e hastes) mas mesmo assim cobrir o solo nas porcentagens encontradas.

Os resultados obtidos aos 7 meses coincidem com os observados por HAGGAR (1972) e KELLY (1972). 


\section{5 - CONCLUSÕES}

Com base nos resultados obtidos no presente trabalho pode-se apontar as seguintes conclusões:

1 - A produção de milho, grãos e planta inteira, não é afetada pela presença da forrageira intercalar, quando há condições adequadas de fertilidade e umidade no solo.

2 - A produção do capim é afetado pela presença do milho principalmente em semeaduras mais tardias em relação ao plantio da cultura.

3 - A modificação do espaçamento favorece o estabelecimento inicial da forrageira porém prejudicou a produção do milho.

4 - A formação de pastagens com milho como cultura acompanhante se mostrou viável como alternativa no estabelecimento de pastagens. 


\section{REFERÊNCIAS BIBLIOGRÁFICAS}

AGBOOLA, A.A. \& FAYEMI A.A. Preliminary trials on the intercropping of maize with diferent tropical legumes in Western Nigeria. Journal of Agricultural Science, Cambridge, 77: 219-25. 1971.

AGROCERES. Semente barata tem mais uma vantagem: é mista. São Paulo, 1988. $4 \mathrm{p}$.

AIDAR, H. \& VIEIRA, C. Cultura associada de feijão e milho. III-Efeitos de populações de plantas sobre o feijão da "seca". Revista Ceres, Viçosa, 26 (147): 465-73, 1979.

AIDAR, H.; CLIBAS, V.; OLIVEIRA, L.M.; VIEIRA, C. Cultura associada de feijão e milho. II . Efeitos de populações de plantas no plantio simultâneo de ambas as culturas. Revista Ceres, Viçosa, 26 (143): 102-11, 1979.

ALCÂNTARA, P.B. Contribuição a regionalização ecológica de plantas forrageiras. Jaboticabal, 1981. 73p. (Mestrado - Faculdade de Ciências Agrárias e Veterinárias de Jaboticabal/UNESP).

ANDRADE, A.G. de, HAAG, H.P.; OlIVEIRA, G.D. de; SARRUGE, J.R. Acumulação diferencial de nutrientes em cinco cultivares de milho. Piracicaba, ESALQ, Departamento de Química, 1977. 106p.

CORSI, M. Estabelecimento de pastagens. In: SIMPÓSIO SOBRE MANEJO DE PASTAGENS, 7., Piracicaba, 1984. Anais. Piracicaba, FEALQ, 1984. p.5-35. 
CRUZ, J.C.; CORRÊA, L.A.; SILVA, A.F. da; OLIVEIRA, A.C.. Avaliação de cultivares de milho associado com feijão. In: CONGRESSO NACIONAL DE MILHO E SORGO, 14, Florianópolis, 1982. Resumos. Florianópolis. ANJOS, J.T. dos; 1982. p.138.

DIAS FILHO, M.B. Espécies forrageiras e estabelecimento de pastagens na Amazònia. In: PEIXOTO, A.M.; FARIA, V.P. de; MOURA, J.C. de., ed. Pastagens na Amazônia. Piracicaba, FEALQ, 1986. p.27-54.

FERNANDES, F.M.; ISEPON, O.J.; NASCIMENTO, V.M.. Resposta de Brachiaria brizantha cv. Marandú a calagem, gessagem e NPK em solo de cerrado. In: REUNIÃO ANUAL DA SOCIEDADE BRASILEIRA DE ZOOTECNIA, 27., Campinas, 1990. Anais. Campinas, SBZ, 1990. p.242.

FERREIRA， C.R.R.P.T; CAMARGO, A.M.M.P. de; TOLEDO, Y.I.M. de; SANTOS, Z.A.P.S. Alguns aspectos econòmicos das pastagens no estado de São Paulo. Agricultura em São Paulo, São Paulo, 37(3):73-97, 1990.

GERALDI, I.O. Método de análise estatística para combinação de cultivares em consórcio. Piracicaba, 1983. 120p. (Mestrado - Escola Superior de Agricultura "Luiz de Queiroz"/USP).

GHISI, O.M.A.A. \& PEDREIRA, J.V.S. Característieas agronòmicas das principais Brachiaria spp. In: ENCONTRO SOBRE CAPINS DO GÊNERO BRACHIARIA, 1., Nova Odessa, 1986. Anais. Nova Odessa. Instituto de Zootecnia, 1987. p. 19-57

GLORIA, N.A. da. Adubação potássica de pastagens. In: CONGRESSO BRASILEIRO DE PASTAGENS '86; SIMPÓSIO DE MANEJO DE 
PASTAGENS, 8., Piracicaba, 1986. Anais. Piracicaba, FEALQ, 1986. p.22530.

GREGOLIN, A.A. Considerações sobre capins do gênero Brachiaria. In: ENCONTRO SOBRE CAPINS DO GÈNERO BRACHIARIA, 1., NOva Odessa, 1986. Anais. Nova Odessa. Instituto de Zootecnia, 1987. p.309-12.

GUSS, A.; PACHECO, B.M., ALENCAR, J.M.; MOLINO, J.A. Efeito do fosfato de Araxá no estabelecimento do capim - marandú (B. brizantha), no Estado do Espírito Santo. In: REUNIÃO ANUAL DA SOCIEDADE BRASILEIRA DE ZOOTECNIA, 27, Campinas, 1990. Anais. Campinas, Sociedade Brasileira de Zootecnia, 1990. p.252.

HAGGAR, R.J. Use of companion cropping grassland establishment in Nigeria. Exploration Agriculture, London, 5(1):47-52, 1969.

KELLY, T.K., Companion crops in pastures establishment. Queensland Agricultural Journal, Queensland, 98(9):497-9, Sept.. 1972.

LOBATO, E.; KORNELIUS, E.; SANZONOWICKS, C. Adubação fosfatada em pastagens. In: CONGRESSO BRASILEIRO DE PASTAGENS '86; SIMPÓSIO DE MANEJO DE PASTAGENS, 8., Piracicaba, 1986. Anais. Piracicaba, FEALQ, 1986. p.199-224.

LUDLOW, M.M. Ligth relations of pasture plants. In: WILSON, J.R., ed. Plant relations in pastures. Melbourne, Commonwelth Scientific and Industrial Research Organization, 1978. p.35-49.

MACEDO, M.C.M. \& ZIMMER, A.H. Implantação de pastagens Brachiaria brizantha cv. Marandú em plantio simultâneo com milho em sucessão a soja em Mato Grosso do Sul. In: REUNIÃO ANUAL DA SOCIEDADE 
BRASILEIRA DE ZOOTECNIA, 27., Campinas, 1990. Anais. Campinas, Sociedade Brasileira de Zootecnia, 1990. p.290.

NUNES, S.G.; BOOK, A.; PENTEADO, M.1.O; GOMES, D.T. B. brizantha cv. Marandú. Campo Grande, EMBRAPA, CNPGC, 1985. $31 \mathrm{p}$. (EMBRAPA/CNPGC - Documentos, 21 ).

PADILLA, C. \& RUIZ T.E. Sorgo forrageiro como cultivo temporal em pastos. La Habana: Inst. de Ciências Animal, 1986. 54p.

REYNOLDS, S.G. Evaluation of pastures grasses under coconuts in Western Samoa. Tropical Grassland, 12(3):146-51,. Nov. 1978.

ROCHA, G.L., Perspectiva e problemas de adubação de pastagens no Brasil. In: SIMPÓSIO SOBRE CALAGEM E ADUBAÇÃO DE PASTAGENS, 1., Nova Odessa. 1985. Calagem e adubação de pastagens. Piracicaba. Associação Brasileira para Pesquisa da Potassa e do Fosfato, 1986. p.1-29.

SANTA-CECÍLIA, F.C. \& VIEIRA, C. Associated cropping of beans and maize. I - Effects of bean cultivars with different growth habits. Turrialba, San Jose, 28(1):19-23, 1978.

SHELTON, H.M. \& HUMPHREYS, L.R. Pasture establishment in upland rice crops at Na Pheng, Central Laos. Tropical Grassland, Queensland, 6(3):223-8, Nov. 1972

SILVA, C.C. \& VIEIRA C. Cultura associada de feijão e milho. V - Avaliação de um sistema. Revista Ceres, Viçosa, 28(156): 194-206, 1981.

VEIGA, J.B. \& SERRÃO, E.A.S.. Sistemas silvo - pastoris e produção animal nos trópicos úmidos: a experiència da Amazònia brasileira. In: SOCIEDADE 
BRASILEIRA DE ZOOTECNIA. Pastagens. Campinas, FEALQ, 1990. p.37-68.

VEIGA, J.B. Associação de culturas de subsistência com forrageiras na renovação de pastagens degradadas em áreas de floresta. In: SIMPÓSIO DO TRÓPICO ÚMIDO. 1., Belém, 1984. Resumos. Belém, CPATU, 1984. p.341.

VIEIRA, C.; RAMALHO, M.A.P.; CHAGAS, J.M. Milho e feijão em cultivo consorciado. Informe Agropecuário, Belo Horizonte, 8(90): 13-5, Jun. 1982.

VIEIRA, J.M. Espaçamentos e densidades de semeadura de Brachiaria decumbens, Staf para formação de pastagens. Piracicaba, 1974. 106p. (Mestrado - Escola Superior de Agricultura "Luiz de Queiroz"/USP).

WILLEY, R.W.. Intercropping - Its importance and research needs. Part. 1. Competition and yield advantages. Field Crop Abstracts, Wallingford, 42(1):1-10. Jan. de 1979.

WILLEY, R.W. \& OSIRU, S.O.. Studies on mixturies of maize and beans (Phaseolus vulgaris) with particular reference to plant population. Journal of Agricultural Science, Cambridge. 79:517-29. 1972.

ZIMMER, A.H.; PIMENTEL, D.M; VALLE, C.B. do; SEIFFERT, N.F. Aspectos práticos ligados a formação de p'stagens. Campo Grande, EMBRAPA/CNPGC. 1983. 42 p. (EMBRAPA. CNPGC. Circular Técnica, 12).

ZIMMER, A.H.; ANDRADE, J.L.R.; SEIFFERT, N.F.; MACEDO, M.C.M. Produção de sementes de Calopogonium mucunoides intercalar a culturas anuais 
de alimentos. In: REUNIÃO ANUAL DA SOCIEDADE BRASILEIRA DE ZOOTECNIA, 23., Campo Grande, 1986. Campo Grande, SBZ, 1986. p.150. 